\title{
Review
}

\section{The Impact of Diet and Exercise on Drug Responses}

\author{
Ellen Niederberger ${ }^{1, *}$ and Michael J. Parnham ${ }^{2,3} \mathbb{D}$ \\ 1 Pharmazentrum Frankfurt/ZAFES, Faculty of Medicine, Institute of Clinical Pharmacology, \\ Goethe University Frankfurt, Theodor Stern Kai 7, 60590 Frankfurt, Germany \\ 2 Pharmacology Consultant, 65812 Bad Soden, Germany; mike.j.parnham@gmail.com \\ 3 EpiEndoPharmaceuticals ehf, Eidistorg 13, 170 Seltjanarnes, Iceland \\ * Correspondence: e.niederberger@em.uni-frankfurt.de; Tel.: +49-69-6301-7616; Fax: +49-69-6301-4660
}

check for

updates

Citation: Niederberger, E;

Parnham, M.J. The Impact of Diet and Exercise on Drug Responses. Int. J. Mol. Sci. 2021, 22, 7692. https:// doi.org/10.3390/ijms22147692

Academic Editor:

Elmira Arab-Tehrany

Received: 11 June 2021

Accepted: 15 July 2021

Published: 19 July 2021

Publisher's Note: MDPI stays neutral with regard to jurisdictional claims in published maps and institutional affiliations.

Copyright: (C) 2021 by the authors Licensee MDPI, Basel, Switzerland. This article is an open access article distributed under the terms and conditions of the Creative Commons Attribution (CC BY) license (https:// creativecommons.org/licenses/by/ $4.0 /)$.

\begin{abstract}
It is well known that lifestyle changes can alter several physiological functions in the human body. For exercise and diet, these effects are used sensibly in basic therapies, as in cardiovascular diseases. However, the physiological changes induced by exercise and a modified diet also have the capacity to influence the efficacy and toxicity of several drugs, mainly by affecting different pharmacokinetic mechanisms. This pharmacological plasticity is not clinically relevant in all cases but might play an important role in altering the effects of very common drugs, particularly drugs with a narrow therapeutic window. Therefore, with this review, we provide insights into possible food-drug and exercise-drug interactions to sharpen awareness of the potential occurrence of such effects.
\end{abstract}

Keywords: drug; pharmacokinetics; pharmacodynamics; exercise; diet

\section{Introduction}

Pharmacological therapy of several different diseases is an important measure for health care systems to reduce mortality and morbidity and to increase the quality of life for patients. A key prerequisite for successful therapy is the efficacy and safety of the drugs used. These parameters are tested in large clinical trials before new drugs are approved. Although this is an accepted process and works well, it has to be taken into account that several factors may alter the drugs' characteristics when used in the general population and lead to pharmacological plasticity [1]. Mutations in the drug target, leading to changes in protein expression or resistance mechanisms are one of these factors. This is the case, for instance, with G-protein coupled receptors (GPCRs) which are widespread drug targets and frequently show mutations [2]. Mutations may be induced by the drugs themselves, as in chemotherapy or, in other cases, by causing the organism to modify the drug [3]. The result, in both cases, is modulation of the patient's drug response. Lifestyle changes may also alter the efficacy of drugs. Aging, smoking, physical activity as well as the composition of an individual's diet and body mass index induce mechanisms which modulate the pharmacokinetics and pharmacodynamics of drugs [4-9].

A healthy diet and exercise are often suggested as beneficial approaches to avoid or cure several diseases. This assumption has been proven in the therapy of type 2 diabetes mellitus, dyslipidemia or cardiovascular disturbances [10,11] (https:/ /www.who. int/health-topics/healthy-diet, accessed on 19 May 2021). However, in many cases, in particular in elderly patients or patients with chronic diseases, a basic therapy with adjusted diet and physical activity is not sufficient to achieve a satisfying therapeutic outcome. Therefore, patients are often placed under additional drug therapy. Since, as mentioned above, exercise and diet are able to modify drug responses, the combination of basic and pharmacological therapy might cause mutual interference, leading to exercise-drug or diet-drug interactions which are similar to drug-drug interactions. Several studies have shown that diet and body composition as well as exercise are lifestyle components that can influence many components of drug metabolism and efficacy $[5,12,13]$. Patients are 
often not aware of the potential risk factors, which are particularly important if drugs with a narrow therapeutic range are used. In this review, we will summarize effects of diet, nutritional state and exercise on the pharmacological plasticity of drugs and will discuss their clinical significance.

\section{Drug Pharmacokinetics and Metabolism}

Therapeutic drugs are subject to mechanisms of pharmacokinetics (PK) and pharmacodynamics (PD) which determine the disposition of the drug in the body (related to drug absorption, distribution, metabolism and elimination (ADME)) and its pharmacological effects (related to its mechanism of action), respectively. It is obvious that changes in these PK/PD parameters can influence the efficacy of the drug as well as its side effects and toxicity.

Absorption is dependent on the administration route of the respective drugs. The most common route of drug administration is orally since it is most convenient for physicians and patients. Most orally-used drugs are absorbed in the gastrointestinal tract (GI). The intestine already contributes to metabolism and elimination of some drugs, while several medications are transferred to the liver in an unchanged manner. Some drugs are then directly transferred to the systemic circulation to reach their target tissue while others are metabolized in a 2-step reaction. Phase I is the biotransformation reaction by hydroxylation, nitrosylation or sulfonation which is followed by phase II, a conjugation step leading for example to glucuronidation of the drug. The most important metabolic enzyme family in phase I is the cytochrome P450 system (CYP) (Figure 1) expressed in liver, gastrointestinal tract and other tissues. These enzymes comprise a variety of isoenzymes and are able to either bioactivate or metabolize drugs in the so-called first pass metabolism (mainly CYP3A4 ( 45-60\% of all drugs) and CYP2D6 ( 30\% of all drugs)) [14-16]. CYP450 activity is particularly interesting for the determination of drug interactions since several drugs are CYP inducers or inhibitors and also food ingredients are able to alter CYP activity and thereby, the drug's pharmacodynamics. Further important players in drug absorption and elimination are transport proteins such as P-glycoproteins (Pgp) or organic anion transporter peptides (OATPs) which are mainly located in the intestines. Pgps are efflux transporters contributing to a lowering of drug concentrations while OATPs are transmembrane proteins which facilitate the uptake of drugs.

The rate and extent of absorption, metabolism and elimination are important parameters for the bioavailability (F) of a drug which indicates the amount of drug that reaches its target site of action. Bioavailability can be determined by calculating the area under the curve (AUC) of peak plasma concentrations $\left(\mathrm{C}_{\max }\right)$ and the time to reach peak plasma concentration $\left(\mathrm{T}_{\max }\right)$. For intravenously (i.v.) administered drugs, $\mathrm{F}$ is $100 \%(\mathrm{~F}=1)$. The determination of the AUC of orally administered drugs in relation to the AUC of i.v. drugs allows the calculation of their absolute oral bioavailability $\left(\mathrm{F}_{\text {oral }}\right)$. In addition, the elimination (drug clearance, CL), characterized by the half-life $\left(t_{1 / 2}\right)$ of a drug in plasma, has an impact on the bioavailability. The rate and extent of drug absorption can be modulated by many factors, such as expression and activity of drug transporter proteins or first-pass metabolism, respectively. The liver is one of the most important metabolic organs. Therefore, changes in liver function caused by altered hepatic blood flow or metabolic capacity can lead to a variability of drug effects. The dietary composition, meaning the quantity of proteins, carbohydrates and fat, but also vitamins and minerals in a meal, contributes to metabolic function, thus indicating that fasting and overnutrition can influence metabolism. In addition, exercise, which leads to alteration in liver blood flow, may have an impact on drug metabolism. 


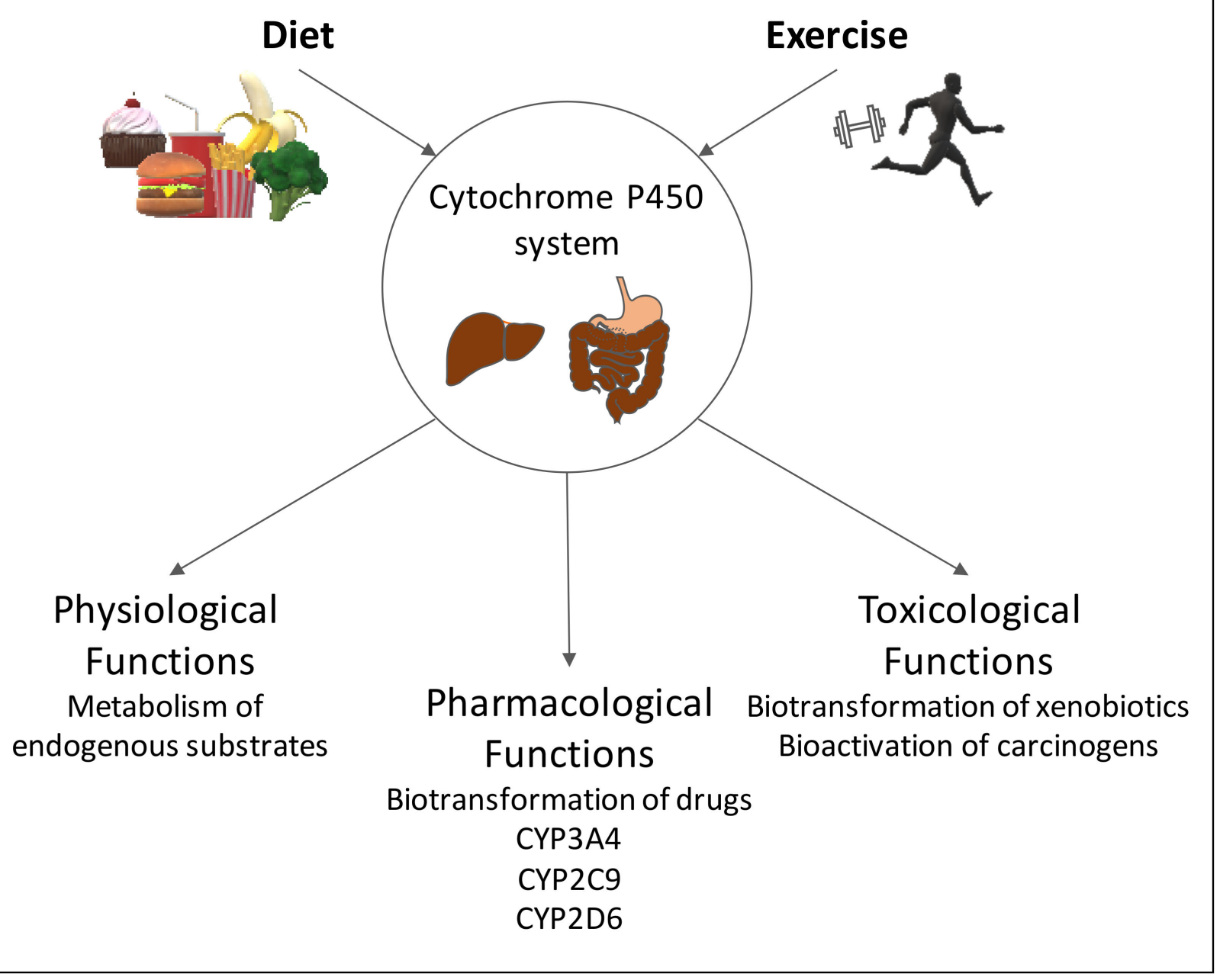

Figure 1. Schematic overview of the influence of diet and exercise on the human CYP450 system.

\section{Diet}

A balanced diet is recommended as a basal non-pharmacological measure for the treatment of several diseases, including diabetes or disturbances in lipid metabolism (https: / /www.who.int/health-topics/healthy-diet, accessed on 19 May 2021). Furthermore, several components of food, drinks and supplemental vitamins and minerals are suggested to support a healthy life. Many dietary products influence a wide variety of different cell types and their physiological signal transduction mechanisms and can thereby, affect their function. In addition, there is increasing knowledge on the pharmacological impact of different food ingredients. Food intake as well as the nutritional status of patients can drastically alter the therapeutic efficacy of drugs which can be of considerable relevance for therapy outcome and the potential for unwanted side effects. Bioavailability, as one of the most important variables for drug efficacy and toxicity is affected by drug absorption and drug metabolism. The amount, composition and also the time point of a meal potentially alters pharmacokinetic processes, either by direct drug-food interaction, by physiological reactions including changes in GI pH, GI motility or bile acid secretion and also by biochemical mechanisms (Table 1). Moreover, the individual body mass (body composition) influences drug pharmacokinetics with respect to absorption, distribution and metabolism of the medication [17-19]. 
Table 1. Physiological changes induced by food and their effects on pharmacokinetics.

\begin{tabular}{|c|c|c|c|c|}
\hline Changes in Physiology & Potential Effects & PK Effect & Examples & Ref. \\
\hline Reduced gastric emptying & $\begin{array}{c}\text { Decreased transport of drug } \\
\text { to intestine }\end{array}$ & Increased $\mathrm{T}_{\max }$ & NSAIDs & {$[20,21]$} \\
\hline Increased blood flow in GI tract & $\begin{array}{l}\text { Saturation of liver enzymes, } \\
\text { avoidance of first pass metabolism }\end{array}$ & AUC and Cmax increase & Propranolol & [22] \\
\hline Increased $\mathrm{pH}$ in stomach & Altered solubility of drugs & $\begin{array}{c}\text { AUC and } C_{\max } \text { for } \\
\text { acids increase } \\
\text { AUC and } C_{\max } \text { decrease } \\
\text { for basic drugs }\end{array}$ & Cefuroxime, Dipyramidol & [20] \\
\hline $\begin{array}{l}\text { Food ingredients alter solubility } \\
\text { of drugs (e.g., lipids) }\end{array}$ & $\begin{array}{l}\text { Lipophilic drugs show } \\
\text { increased solubility }\end{array}$ & AUC and $C_{\max }$ increase & Fenofibrate & [23] \\
\hline $\begin{array}{l}\text { Inhibition of GI enzyme or } \\
\text { transporter activity }\end{array}$ & $\begin{array}{c}\text { Decrease in drug metabolism, } \\
\text { decreased efflux } \\
\text { Decreased drug uptake }\end{array}$ & $\begin{array}{l}\text { AUC and } C_{\max } \text { increase } \\
\text { AUC and } C_{\max } \text { decrease }\end{array}$ & $\begin{array}{l}\text { Sirolimus, Midazolam } \\
\text { Fexofenadine }\end{array}$ & {$[24,25]$} \\
\hline
\end{tabular}

\subsection{The Impact of Body Weight}

Body weight and obesity are known to be important factors in drug metabolism. Increase in body weight as a result of increased muscle mass is generally a healthy approach as the percentage of fat decreases. Obese people have a higher mass of fat and of lean tissue; however, the percentage of lean tissue per $\mathrm{kg}$ total body weight is reduced compared to normal-weight persons [26]. In addition to an increase in adipose tissue, the massive increase in body weight alters physiological functions such as cardiac output, as well as changes in blood flow distribution and body water which contribute to modified pharmacokinetics of drugs in obese individuals [18]. It has already been suggested that drug therapy has to be adjusted in these people, but specific recommendations are generally lacking and therefore, careful therapeutic drug monitoring is necessary in obese patients [27]. Absorption after oral administration shows no significant changes in these patients [18], but due to an increase in subcutaneous adipose tissue, drug absorption after subcutaneous or intramuscular administration might be changed [28,29]. Drug distribution and bioavailability cannot be directly predicted by body changes in obese individuals but strongly depend on the physicochemical properties of the respective drugs [18]. In the last 50 years or so, there have been a lot of clinical trials on CYP-mediated drug metabolism in obese and normal weight individuals, as well as effects of dietary compositions on the pharmacokinetics of different drug classes [7].

Cytochrome P450 enzymes constitute the best-known pharmacokinetic system which is responsible for the metabolism of about $70-80 \%$ of the drugs on the market. The liver is the major site of CYP450 expression and activity, but enterocytes in the epithelium of the small intestine are also involved in CYP-mediated metabolism. The major CYP enzymes contributing to drug metabolism comprise CYP1A2, CYP2C9, CYP2C19, CYP2D6 and CYP3A4 with CYP3A4 accounting for about $45-60 \%$ of drug metabolism, for instance that of statins, benzodiazepines or chemotherapeutics [14-16]. The activity of these enzymes is considerably affected by body weight and obesity with CYP3A4 activity being reduced and CYP2E1 activity increased by obesity, as indicated, for instance, by reduced clearance of alfentanyl or triazolam (Cyp3A4 substrates) and an increase in clearance of halothane or chlorzoxazone (Cyp2E1 substrates). So far, data on CYP1A2, CYP2D6 and CYP2C19 activities are inconclusive, although a tendency towards increased activity has been observed [30,31].

To date, less is known about effects of severe underweight on the CYP system. A clinical study investigating the activity of CYP1A2, CYP2C9, CYP2C19, CYP2D6 and CYP3A4 in patients with anorexia nervosa, again delivered hints that the body mass index (BMI) correlates with the metabolic activities of the enzymes. The metabolic activity of CYP3A4 decreased, while CYP1A2 increased at a higher BMI. CYP2C9, CYP2C19 and CYP2D6 remained unaltered [32], indicating that CYP3A4 substrates, such as statins or Cyp1A2 substrates like theophylline, might show differences in their efficacy or toxicity, respectively. A further study supported these data showing higher CYP3A4 activity in underweight 
patients in comparison to normal-weight controls [33]. These results indicate an inverse relationship between body weight and CYP3A4 activity which might have clinical relevance for specific drug therapies. The determination of renal clearance in obese patients is again difficult and depends on the extent of kidney function which is often disturbed in these people [34].

\subsection{The Impact of Nutrition}

The content and composition of meals with regard to macro- and micronutrients, as well as timing of meals in relation to drug uptake, have a strong influence on the metabolism and bioavailability of drugs $[35,36]$. These food-drug interactions have already been known for a long time and are as important as drug-drug interactions. Some medications are affected by food uptake in general, with a simultaneous meal leading to an increased or decreased absorption of the drug, irrespective of the meal composition and largely dependent on the physiochemical properties of the drugs (see Table 1). Therefore, coadministration of drugs and food may be associated with increased bioavailability of a drug, thereby enhancing its efficacy but also its potential side effects. On the other hand, food can decrease the absorption of drugs, reduce their bioavailability and thereby the efficacy of the therapy. Other drugs react with certain food components like proteins (for example, propranolol), fat (for example, cyclosporine), carbohydrates (for example, theophylline) or vitamins (for example, warfarin) or specific types of meals [37]. These potential interactions already show that it is important to raise the awareness of patients and doctors and to consider potential food-drug interactions in the development of new medicines in the future.

Taking this problem into account, the FDA recently published recommendations for the development of novel therapeutics (2019, https://www.fda.gov/media/121313 /download, accessed on 19 May 2021). According to these guidelines, pharmacokinetic parameters of new drugs including $A U C, C_{\max }, T_{\max }$ and $T_{1 / 2}$, clearance should be determined in clinical studies in individuals under different nutrition states. It is suggested that a high fat-high calorie meal will have the biggest effect on drug pharmacokinetic properties. Nevertheless, these recommendations do not by any means cover the whole spectrum of dietary habits of patients. Furthermore, it makes a difference if meals are taken only occasionally or if they represent prolonged dietary changes. A huge number of studies has been performed so far to assess effects of diet on a variety of different drugs. Therefore, in this review, it is only possible to give some examples of food-drug or nutrient-drug interactions and not to cover the whole range of potential interactions.

\subsubsection{Effects of Macronutrients}

Macronutrients are carbohydrates, lipids and proteins in food serving primarily as an energy supply. In addition, these food ingredients have different impacts on drug metabolism. Fat-, protein- and carbohydrate-content of a meal differentially alters the properties of drugs and their metabolism.

In general, high-fat food leads to lowered gastric emptying [38]. The solubility of hydrophilic drugs can be decreased while a high fat content can increase the solubility of hydrophobic drugs which, for instance, is the case for antifungal itraconazole (lipophilic) or the beta-blocker atenolol (hydrophilic), showing increased and decreased bioavailability after high fat meals, respectively [39,40]. Furthermore, high-fat food alters several physiological processes such as bile acid secretion, intestinal lymphatic transport pathways and transporters in the gut [41]. Thus, high-fat diets have been shown to alter the disposition of cyclosporine by increasing its clearance [42]. Such diets also have selective effects on drug metabolizing enzymes. In a recent study on five different drugs, each metabolized by a different CYP, it was shown that the high fat diet increased exposure to the benzodiazepine sedative midazolam and gastric proton pump inhibitor omeprazole, indicating modulation of CYP3A4 and CYP2C19, respectively [43]. This is further confirmation of the 
fact, discussed above, that these two CYPs are targeted by lifestyle changes in metabolism, though the effects of high fat intake appear to differ from those of obesity.

Food contains different types of fat which can be roughly divided into unsaturated (mono- or polyunsaturated) and saturated fats. Several essential polyunsaturated fatty acids (PUFAs), such as linoleic or arachidonic acid, are metabolized by cytochrome P450 epoxygenases to biologically active epoxyeicosatrienoic acids (EETs) [44]. PUFAs are associated with a number of beneficial health effects, particularly due to their antiinflammatory properties, but there are also hints that they may interact with certain drugs [45]. However, despite clear evidence of interactions with CYPs and an immense literature on the effects of dietary PUFAs on health and disease, there appear to be no or very few studies on the effects of a specific PUFA diet on drug metabolism. On the other hand, it has been shown that pharmacodynamic properties can be altered by specific types of fats.

PUFAs constitute components of cell membranes and it has long been known that an increase in PUFA intake results in enhanced fluidity of biological membranes [46]. In view of the fact that receptors for drugs are frequently membrane proteins, it would be most surprising if a high PUFA diet had no effect on the pharmacodynamic effects of drugs. For instance, an increase in membrane fluidity (induced by benzyl alcohol) has recently been shown to promote transcriptional upregulation of glucocorticoid receptordependent genes [47]. A few examples with PUFAs also exist in the literature. Thus, the essential omega-3 polyunsaturated fatty acid docosahexaenoic acid (DHA) exhibited a marked propensity to interact with both adenosine A2A and dopamine D2 receptors, leading to an increased rate of receptor oligomerization. It has been suggested that higher levels of PUFAs ameliorate neurodegenerative diseases which could potentially have important implications for drug therapy of neuropsychiatric conditions like schizophrenia or Parkinson's disease [48]. In animal models, substitution with specific PUFAs has already shown protective effects against neurodegeneration [49]. Pardini found that an enhanced nutritional uptake of PUFAs, particularly long chained omega-3-FAs, increased membrane fluidity, increased activity of selected drug activating enzymes, altered signaling pathways important for cancer progression and enhanced transport capabilities for selective anticancer agents leading to their accumulation in the tumors [50]. These changes in tumor fatty acid composition resulted in enhanced sensitivity to chemotherapy, especially in tumor lines that are resistant to chemotherapy, suggesting that long chained omega-3 PUFA supplementation may be beneficial in tumor chemotherapy. More extensive studies of the interactions between PUFA supplementation and various drugs would seem to be warranted.

High protein meals also exert different effects on drugs. The blood flow in the GI tract increases upon a protein-rich meal and enhances drug absorption. However, proteinderived peptides might compete with drugs for transporter proteins leading to lowered absorption rates. This might be of relevance, for example, for the anti-Parkinson drug levodopa or beta-lactam antibiotics which are also dependent on transporter proteins for uptake [51]. On the other hand, proteins are suggested to increase intestinal transporters. Furthermore, protein-rich meals can have an impact on enzymes in drug metabolism and may alter the bioavailability of several drugs [41]. It has been shown that a switch to a high-protein/low-carbohydrate-containing diet can increase the clearance of betablocker propranolol by $74 \%$ and that of theophylline by 32\% [52]. In contrast, highcarbohydrate/low-protein meals decrease the clearance of theophylline used in asthma therapy [53]. In clinical studies with patients with asthma or airway obstruction, a highprotein diet was associated with higher clearance rates of theophylline which affected the therapy [54,55]. Furthermore, changes in bioavailability have been described for the immunosuppressive agent tacrolimus which has a higher absorption rate after a highprotein meal as compared to a high-fat meal [56].

Carbohydrates are a heterogeneous group of food components which occur as mono-, di-, oligo- and polysaccharides, both digestible and non-digestible. Therefore, it is relatively 
difficult to clearly evaluate their effects on metabolism. As indicated before, a switch from low to high or high to low carbohydrate diet is associated with changes in drug clearance of theophylline by changes in CYP1A2 activity [53] and of phenytoin by alterations in CYP2C9 and CYP2C19 [57].

As alluded to previously, several studies show that the activity of the CYP system can be strongly altered by the composition of a meal in terms of protein, carbohydrate and fat content (summarized in [7]). The different macronutrients affected CYP450 enzymes differentially but the findings were not always conclusive. The activity of CYP1A2 seems to be increased by a high protein diet and fasting, but is reduced by high carbohydrate diet. In addition, the activity of CYP2C9 is decreased by fasting and increased by overnutrition. In contrast, CYP2C19 was shown to be non-susceptible to fasting or high protein diets $[58,59]$. Other groups investigated effects of fasting on drug metabolizing enzymes and found that a $36 \mathrm{~h}$ withdrawal of food and drink, except water did not significantly influence the activity of several CYP enzymes. However, CYP1A2, CYP2D6 and CYP 3A4 activities were significantly increased after fasting while CYP2C9 was decreased. These changes in drug metabolism were associated with increased caffeine, metoprolol and midazolam and decreased warfarin clearance and a modified efficacy of the drugs [58,60]. In addition to first phase metabolic enzymes, regulation of second phase enzymes (Uridine $5^{\prime}$-DiphosphoGlucuronosyltransferase (UGT)1A4/2B4/2B) was also observed after fasting, leading to decreased midazolam metabolism [60].

\subsubsection{Dietary Supplementation with Micronutrients and Bioactive Compounds}

Micronutrients are essential dietary factors which are needed by human organisms for proper physiological functions. In contrast to macronutrients, micronutrients are required only in low amounts and comprise, for example, vitamins and minerals. They act mainly as enzymatic cofactors but are not needed for energy production and anabolism. Bioactive compounds are a class of non-essential micronutrients and comprise, among others, different polyphenols derived from plants (phytochemicals) [61,62].

There is an ongoing trend to supplement "normal" alimentation with vitamins or multivalent cationic minerals which might affect drug properties [63]. Minerals are reported to exhibit so-called antacid interaction leading to complex formation, changes in adsorption, gastric and urinary $\mathrm{pH}$ and clearance of drugs [64-66]. Similar to fruit juices, food supplements containing flavonoid or antioxidant components can induce changes in drug PK and PD. As an example, paracetamol, a potent antinociceptive and antipyretic drug, and statins, lipid-lowering drugs, can be modulated by antioxidative food supplements or phenolic phytochemicals [67]. A recent review of clinical interactions with CYPs identified CYP-based interactions between 261 herbal, food and dietary supplements and 117 anticancer drugs [68].

\subsubsection{Phytochemicals}

Different polyphenols are produced by plants for protection against several environmental threats such as UV. The group of plant polyphenols comprises flavonoids, phenolic acids, coumarins, stilbenes and lignans. They are ingredients of vegetables, fruits and nuts and associated with beneficial effects on health [69]. These polyphenols are thus, taken up in the diet, for instance, as epicatechin in cocoa, epigallocatechin gallate in green tea, anthocyanins in berries or quercetin in onions. Plant polyphenols, in particular epicatechins, have also been associated with decreases in insulin resistance, possibly by interaction with beta-cell damaging reactive oxygen species, glucose transporters or through antiinflammatory mechanisms [70]. These beneficial properties might increase the efficacy of therapeutic measures against the development of diabetes.

Flavonoids in food have positive properties in that they exert anti-inflammatory actions and hepatoprotective effects but they are also able to modulate metabolism, efficacy and toxicity of drugs, among other mechanisms by modulation of CYP450, glucuronyltransferases and transporter proteins [71]. Very common examples are bioflavonoids in 
fruit juices, particularly grapefruit juice, which alter CYP450 enzymes as well as several transporter proteins such as Pgp, multi-drug resistance proteins (MDR) or OATPs [72-74]. Several studies indicated that bioflavonoids such as naringin or naringenin in grapefruit juice lead to inhibition of CYP3A4 and OATP1 and 2. By inhibition of CYP3A4, they induce an increase in the bioavailability of drugs such as calcium channel blockers, benzodiazepines, and lipid-lowering statins which are CYP3A4 substrates. These modulations in bioavailability might then be associated with serious adverse effects, including changes in ECG, or rhabdomyolysis, a pathological breakdown of skeletal muscle [75,76]. Inhibition of OATPs by grapefruit juice is associated with decreased intestinal absorption of drugs acting as transporter substrates, such as antihypertensive ACE inhibitors [77]. Further studies showed that a number of other fruit juices (e.g., apple and orange) are also able to change the pharmacological effects of drugs by altering activity and expression of intestinal OATP1A2, CYP3A4 or Pgp or by direct interaction with the drugs [74]. However, other reports indicate that it is difficult to estimate the pharmacodynamic outcome of these effects due to a high variability of fruit juice composition and the differences among individuals [78,79]. Furthermore, the daily uptake of grapefruit juice is moderate in most countries and therefore, only a few cases might contribute to the clinical relevance of fruit juice-drug interactions [80].

A further important contribution to diet regimens to date can be attributed to soya products with a high isoflavone contents. Vegetarian and vegan diets as well as Asian foods are mainly based on soya and the number of people who replace meat by plant food is constantly increasing. Isoflavones may lead to modification of CYP enzymes and other cellular proteins involved in drug metabolism [81]. Clinical studies have shown that genistein, one of the main isoflavones in soya, induces a decrease in CYP1A2 and CYP2A6 activity $[82,83]$ while causing a slight induction of CYP3A4 [84]. Flavonoids, at least in vitro, are able to counteract the generation in the liver of the reactive metabolite of paracetamol by inhibiting human hepatic CYPs, thereby reducing paracetamol liver toxicity [85].

An essential regulator of cellular antioxidant response is the transcription factor Nrf2. It is known as the master regulator of redox homeostasis and regulates nearly 600 genes involved in cellular protection against factors contributing to oxidative stress, including aging, disease and inflammation [86,87]. Flavonoids are not only antioxidant as a consequence of their ability to scavenge oxygen radicals, but more specifically through activation of Nrf2. This probably occurs by Michael addition between the polyphenols and cell surface thiol groups [86,88-90]. This activation of Nrf2 contributes to the antiinflammatory activity of flavonoids and will modulate hepatic oxidative metabolism and potential hepatic toxicity of a number of different drugs [91]. Based on the same mechanism, it has been proposed, though, that flavonoids may also interfere with the effects of cancer chemotherapy [92]. It is often reported that vegetables from cruciferous plants (e.g., broccoli, spinach) contain indoles which can modify the metabolism of specific drugs. It is proposed that they modify CYP450 as well as phase II enzymes which might influence, for instance, the metabolism of phenacetin and paracetamol $[93,94]$. Furthermore, it was shown that diets containing broccoli or cabbage and Brussel sprouts increased elimination of caffeine metabolites (CYP1A2) [95]. Watercress decreased the activity of CYP2E1 and increased the bioavailability of the muscle relaxant chlorzoxazone, while decreasing the production of analgesic paracetamol metabolites $[96,97]$.

\subsubsection{Minerals}

Minerals are essential chemical elements which are required for the proper functioning of a living organism. They are taken up with food and comprise calcium (e.g., in dairy products), phosphorus (e.g., in meat), sodium (e.g., in table salt), potassium (e.g., in vegetables) and magnesium (e.g., in nuts) as well as trace elements such as iron, zinc or selenium. In addition to intake with food, these substances are frequently ingested by many people as food supplements. Several minerals are able to interact with drugs with different characteristics. Most interactions are known for calcium in milky products. 
Calcium can change the uptake of several drugs, such as the antibiotic fluoroquinolones or the antirheumatic/anticancer agent, methotrexate. Furthermore, milk inhibits the uptake of trace elements like iron. In addition, it is known that $\mathrm{Ca}^{2+}, \mathrm{Mg}^{2+}$ and $\mathrm{Fe}^{2+}$ can form complexes with drugs and thereby, change their solubility which has been shown for several antibiotics [98]. For this reason, the antibiotic tetracycline should not be given with dairy products, calcium or multivitamin supplements [99].

\subsubsection{Vitamins}

The inhibitory effect of vitamin K-rich food (e.g., lettuce, avocado or liver) on the activity of warfarin, a common inhibitor of blood coagulation, is one of the best known examples of vitamin-drug interactions. Vitamin $\mathrm{K}$ is an essential component of the bloodclotting process which is inhibited by warfarin. Continuous uptake of vitamin K-rich foods can lead to warfarin resistance and to a requirement for dose adjustment $[100,101]$. Folic acids can also alter the metabolism of drugs. Thus, it has been shown that folic acid leads to a decrease in the plasma concentration of the anticonvulsant diphenylhydantoin [102,103]. Furthermore, vitamin C competes with estradiol for sulfate conjugation in the intestine and thereby, induces an increase in the bioavailability of estradiol which might impact on contraceptive drug efficacy [104,105]. In addition to these changes, vitamin C is suggested to be involved in a number of metabolic pathways, including glutathione recycling or catecholamine synthesis. By affecting the synthesis of neurotransmitters, it might also alter the need for analgesic drugs [106]. A and D vitamins are also associated with changes in CYP450 activity. Deficiency of vitamin A mainly inhibits the activity of various CYP enzymes, while supplementation with vitamin A enhances their activity [107]. Vitamin D may induce CYP3A4 which might be associated with reduced bioavailability of CYP3A4 substrates, such as ketoconazole or midazolam [108]. A wide variety of antioxidant dietary supplements, including vitamins $\mathrm{A}, \mathrm{E}$ and $\mathrm{C}$ are also able to activate Nrf2, and will thus modify oxidative metabolism of drugs [109].

\subsection{The Role of the Microbiome}

The human microbiome describes the occurrence and variety of microorganisms in the human body. It comprises mainly bacteria, but also viruses, fungi and protozoa and colonizes several tissues, mostly gut, skin and nose. The microbiome shows marked inter-individual variability and is highly adaptive. In a physiological, healthy state, the microbiome contributes to body homeostasis, while disturbances of the homeostatic balance have been associated with diseases such as inflammatory bowel disease, atherosclerosis or Alzheimer's disease [110,111].

A complex bidirectional interaction between several drugs and the gut microbiome is well established. Antibiotic and non-antibiotic drugs are both able to influence the microbiome of patients. However, the microbiome can also impact the clinical efficacy of drugs by enzymatically altering the structure and metabolism of the drug and thereby, its bioavailability, a phenomenon that has been entitled pharmacomicrobiomics. Germ-free animal models indicate that the microbiome can influence the gene expression of metabolic proteins and alter the efficacy of several drugs [112-114], thereby also contributing to pharmacological plasticity.

As mentioned above, most drugs are administered orally and have to pass the gastrointestinal tract where they come in contact with commensal microbes in the gut. Since microbes express a high variety of genes, the effects of drugs might be altered by the occurrence of drug-metabolizing enzymes produced by microbes or by direct interactions between microbes and drugs. These interactions may occur as direct effects of the microbial enzymes on drug metabolism or as indirect effects of microbial metabolites acting on signal transduction pathways of the host $[115,116]$. A study which investigated the metabolism of 271 drugs by human gut bacteria, revealed that about two-thirds of the drugs are metabolized by the bacterial strains. Microbiome-encoded metabolic enzymes contribute to the formation of the metabolites [117]. However, metabolic pathways catalyzed by hepatic 
enzymes of the host and enzymes of the microbiome are clearly different. In the liver, drugs are metabolized by oxidative and conjugative reactions while the gut microbiome induces hydrolytic and reductive reactions that contribute to drug metabolism [118]. It is also known that the microbiome can lead to individual-specific alterations in drug responses, as shown for instance, in cancer treatment with PD-1 immunotherapy $[119,120]$.

Changes in the microbiome can be initiated by several factors including drug administration, circadian rhythm, exercise and diet. It is suggested that diet-induced modulation of the microbiome might contribute to beneficial effects of a diet in diverse diseases. So far, carbohydrates are the best studied nutrients, influencing the microbiome by serving as a major energy source for bacteria while functions of proteins and fat have gained less attention [121]. Dietary alterations can rapidly change the bacterial composition of the gut by promoting the growth of specific bacterial groups. For instance, diets containing plant proteins, unsaturated fats or probiotics, increased the quantity of the bacterial species Lactobacillus and Bifidobacteria which might contribute to beneficial health effects in a Mediterranean diet, while Western diet decreases these bacterial strains associated with the development of several diseases [111]. Some reports have already discussed whether these effects could be used as therapeutic measures for precision therapeutic nutrition. In addition, diet-induced changes in the microbiome have an impact on the immune system, an effect which might also be useful for personalized nutritional approaches [122,123]. However, it is not clear so far whether long-term dietary changes are able to induce a permanent shift in the microbial composition although there are data showing a change in gut microbial enterotypes after a long-term diet [124]. Several reports indicate that uptake of proteins is associated with a high diversity of microorganisms. However, this might lead, for instance, to an increased risk of developing inflammatory bowel disease, in particular with high consumption of animal proteins $[125,126]$.

High uptake of saturated fatty acids is associated with a lower diversity of microbiota in humans, while PUFAs may increase the occurrence of several bacteria associated with anti-inflammatory and anticancer effects $[127,128]$. The amount of fat in the diet also shifts the composition of different microorganisms in the gut, which is associated with reduced concentrations of fasting glucose and cholesterol on a low-fat diet [129]. Carbohydrates also alter the microbiome in a variable manner depending on the carbohydrate type and the amount of uptake. Digestible carbohydrates are metabolized to glucose and stimulate the release of insulin while non-digestible carbohydrates such as fibers produce prebiotics. Prebiotics are associated with several health benefits induced by mechanisms involving the gut microbiome, such as improvements in metabolic disorders [130]. So far, there are only a few studies which have directly investigated food-induced changes in the microbiome and their impact on drugs. Current data available indicate that polyphenolrich nutrition, for instance, influences a specific bacterial strain (Akkermansia) in the gut, thus potentially contributing to an increased response to antitumor therapy with PD-1 blocking antibodies $[119,131]$.

\subsection{The Role of the Immune System}

The uptake of different types of nutrients not only affects the pharmacokinetics of drugs but may also indirectly alter drug responses by modulation of the immune system, for instance, by modifying the microbiome as mentioned above, potentially also affecting actions of immunomodulatory drugs. Many food constituents, including flavonoids, exert immunomodulatory and anti-inflammatory activities which contribute to the beneficial health effects of a balanced diet and of food supplements [132]. Zinc and selenium are trace elements in food which, among many other effects, are essential for healthy innate immune cell function by regulating T-cell signaling, phagocytes and NK cell activities and ensuring effective defense against pathogens and tumors [133,134]. In addition, zinc is a cofactor for thymulin which ensures normal differentiation and maturation of $\mathrm{T}$ lymphocytes. Selenium is essential for the activity of the hydroperoxide degrading enzyme, glutathione peroxidase which protects against oxidative injury to cells, including immune cells, and 
tissues. Vitamin $\mathrm{E}$, which is active against oxidative damage to lipids and vitamin $\mathrm{C}$ which is a soluble antioxidant factor, also contribute to the protection of the organism against oxidative injury. Since vitamin $C$ is a cofactor for the biosynthesis of CYPs, deficiency is clearly likely to have effects on the metabolism of a number of drugs. Drug interactions due to excessive vitamin $C$ supplementation, on the other hand, are unlikely as it is rapidly excreted in the urine. Deficiencies in Vitamin $\mathrm{E}$ are associated with disturbances in innate and adaptive immunity [133]. D vitamins also affect both the innate and adaptive immune system, showing stimulatory effects on innate immune cells while T and B-cells are inhibited, which might reduce autoimmune reactions reinforcing responses to antiinflammatory drug therapy.

Dietary fatty acids contribute to the cellular uptake of PUFA substrates for inflammatory lipids such as prostaglandins, leukotrienes and hydroxy-fatty acids and thereby to inflammatory responses [135]. On the other hand, some PUFAs, such as the omega-3-fatty acids in fish oil, lead to the formation of different types of prostaglandins and leukotrienes which are not inflammatory and promote inflammation resolution $[13,136]$. These dietinduced effects may then support-as with fish oil-or inhibit—as with other fatty acid oxidation products-drug efficacy. In addition, dietary PUFAs are incorporated into all cell membranes and enhance the fluidity of the membranes. As a consequence, responses of both the innate and adaptive immune systems are modified, epithelial barrier protection enhanced and the activation of nuclear and transmembrane receptors altered [137]. Such effects have been observed on cholesterol efflux from human macrophages and atherosclerosis [138], in relation to neurotransmitter signaling in both depression and schizophrenia [139,140], as well as on viral infection of cells [141], with inevitable modifying consequences for the efficacy of drug therapy.

In summary, it can be assumed that food habits vary tremendously between individuals, just taking into account the fact that different people eat meat, are vegetarians or vegans. Some people eat low-carb, others follow high protein diets, etc. Therefore, it is very difficult to provide an overview of all potential effects of diet on diverse drugs. A problem with food-drug interactions is that they are not generally predictable. There is a huge variability in drug formulations, characteristics of the meals and the time of drug intake in relation to the meal. In addition, the "reactive" ingredients in food are often not clear. So far, effects of food on drugs have mostly been evaluated in clinical studies which are cost intensive and take a lot of time. Furthermore, clinical studies often do not provide mechanistic insights into the food-drug interaction. Novel approaches suggest that it might also be possible to apply physiologically based pharmacokinetic (PBPK) models that combine drug properties and physiological data to predict mechanisms and potential clinical relevance of food effects. With these models, it should be possible to estimate the food effects and their magnitude with regard to pharmacokinetic parameters [142-144]. Although establishing these models affords in vitro and in vivo verification at the start, at later stages these approaches would provide large health benefits.

\section{Exercise}

Similarly to diet, exercise is often a basal therapy for several disturbances and can improve symptoms of cardiovascular diseases such as hypertension or high blood glucose levels in diabetes patients $[145,146]$. Furthermore, physical activity can ameliorate pathologies of the nervous and the immune system (such as Alzheimer's disease or depression, inflammatory diseases) $[10,11]$. It is recommended by physicians, often in combination with a pharmacological therapy for the underlying disease(s). In common with diet, exercise and drugs also interact with each other in a bidirectional manner. Several medications may alter exercise performance, while exercise has an impact on the efficacy of drugs as well. However, the impact of exercise on the pharmacokinetics of drugs is complex and depends on the drug characteristics as well as on exercise-related conditions, such as mode, duration and intensity of exercise. Nevertheless, the impact of certain types of physical activity 
should be considered in relation to pharmacological therapy and in the development of novel drugs.

Physical activity (PA) can be roughly distinguished into acute and long-term (chronic) as well as aerobic or resistance exercise. These different forms of activities are associated with acute and chronic changes in physiology which can range from short time adaptation within minutes to hours, as well as long term adaptation over a period of days or weeks. The changes apply to cardiac output, body temperature, gastric motility, plasma volume, plasma proteins, body composition, heart and skeletal muscle capillarization, as well as tissue mitochondrial density. All these adaptations can affect drug pharmacokinetics and -dynamics. Although the awareness of these exercise properties is increasing, there are only limited data on the effects of exercise on drug efficacy in patients. Long term health benefits of exercise are often ascribed to changes in the expression and activity of proteins but these changes are often short-lived and maintained only for several hours after exercise. However, repeated exercise can also lead to accumulation of changes if the intervals between PA are short and the half-life of the effect is long [147]. In this regard, such exercise can have strong effects on the expression and activity of metabolic enzymes.

PA affects the pharmacokinetics of drugs in the exercising individual in terms of absorption, distribution, metabolism and excretion, and may thereby modulate $C_{\max }, T_{\max }$, $t_{1 / 2}$ and $F$. One main factor determining exercise-induced adaptations is a change in blood flow distribution which affects the physiology of several organs and the blood composition. This may also have an impact on plasma protein binding of the drugs and may affect their efficacy, since only unbound drugs can induce an effect.

\subsection{Exercise and Drug Absorption}

During exercise, the cardiac output increases and blood flow is shifted to increased perfusion of skin and muscles, thus leading to decreased blood support of inner organs $[148,149]$. Depending on exercise intensity, this can lead to decreased gastric motility and emptying associated with delayed drug absorption. Furthermore, the increased transit time in the GI tract might support interaction of the drug with gastric acid secretion and enzymes which may lead to changes in solubility, metabolism and transporter influx/efflux. However, this is not the case in chronic aerobic exercise which induces a shortening of the transition of solid food through the stomach and an increase in GI permeability $[150,151]$. In any case, these changes can influence the bioavailability of drugs. Gastric acid secretion and concentrations of $\mathrm{HCl}$ are lower during exercise, leading to facilitated translocation of unionized basic drugs into the vasculature, while acidic drugs show higher rates of ionization and will thereby be retained in the GI to a higher degree. In addition to changes in the gastrointestinal tract, which will most probably affect absorption of orally administered drugs, the increased blood flow in the working muscles during exercise can have an impact on the absorption of subcutaneously or transdermally administered drugs, associated with increased skin temperature and increased hydration. For instance, it has been shown that subcutaneously injected insulin shows a higher absorption rate in working muscles resulting in further lowering of plasma glucose levels [152]. Moreover, transdermal absorption of nitroglycerin and nicotine from patches can be increased by exercise [153]. Intramuscular injections of penicillin and diazepam also delivered higher plasma concentrations after exercise in comparison to resting controls [154,155].

\subsection{Effects on Drug Distribution}

Several studies have also indicated drug distribution changes as a result of exercise. During acute exercise, the concentration of plasma proteins shows a relative increase due to a decrease in plasma volume [156]. On the other hand, regular aerobic exercise leads to an increase in the plasma volume [157]. Both conditions affect drug concentrations in the plasma as well as distribution and elimination by changes in plasma protein binding and distribution of the unbound drug [156]. Distribution might also be affected by the changes in blood flow which hinder the drug from reaching its target tissue. Several clinical studies 
indicate that beta-blocking drugs, for instance, show a change in their distribution during exercise, but it has not been clarified whether the changes are associated with modified drug action $[158,159]$. In addition to changes during acute bouts of exercise, chronic regular exercise leads to a switch from adipose tissue to fat-free body mass. Adipose tissue is less hydrated and perfused indicating that fat reduction increases bioavailability and distribution of drugs which are dependent on the physiochemical properties of the respective drug $[13,18]$. In addition, it is known that exercise induces release of free fatty acids (FFAs) from adipose tissue and their shift to the blood circulation. The FFAs can then competitively hinder drug-protein binding which has been shown in rats, for example, where exercise-induced FFA increases could be correlated with increased ampicillin levels in serum and tissues [160]. Clinical studies supporting these effects are still lacking. The distribution and metabolism of drugs is also affected by an exercise-induced increase in heart and skeletal muscle capillarity and in mitochondria [147]. The increased blood circulation enhances drug distribution while more mitochondria can affect the activity of drug metabolizing enzymes [13]. Both effects might occur concomitantly, since changes in blood flow are able to directly affect mitochondrial biogenesis and activity, as shown in studies using blood-flow restriction exercise [161].

\subsection{Exercise and Drug Metabolism}

As mentioned above, drug metabolism occurs mainly in the liver by the action of CYP450 enzymes. Changes in hepatic blood flow during exercise may influence hepatic metabolism and clearance of drugs. However, this is at least partially dependent on the drug hepatic extraction rate. Drugs with low hepatic extraction are only dependent on changes in blood flow to a limited extent, while metabolism of drugs with high hepatic extraction can be drastically modified by blood flow alterations [162]. Another factor is that acute exhaustive exercise is associated with several inflammatory effects $[163,164]$ which may influence the metabolism of drugs, such as by downregulation of mRNA synthesis of metabolizing enzymes [14]. This might occur in association with epigenetic effects of exercise, as has been shown for adenosine monophosphate kinase, for example, a key metabolic enzyme, which showed modified methylation in blood and skeletal muscle cells after exercise [165]. In contrast, specific types of chronic exercise have been linked to upregulation of metabolizing enzymes, leading to increased clearance, potentially due to an increase in liver size and CYP450 content [166]. A further effect of exhaustive exercise is accumulation of lactate which decreases the blood $\mathrm{pH}$. This might affect the metabolism of basic drugs which have an increased unbound fraction in acidic environment, while acidic drugs show a higher protein binding capacity (e.g., to albumin) [167].

\subsection{Effects of Physical Exercise on Drug Excretion}

Exercise can also affect excretion of drugs from the circulation which is mainly performed by urine and bile. Due to decreased blood flow in inner organs, the glomerular filtration rate in the kidney can decrease up to $30 \%$ during exercise performance depending on exercise intensity [156]. Therefore, drugs which are secreted in an unchanged form are most likely affected by exercise and may show an accumulation in the plasma as has already been shown for several drugs including atenolol or procainamide [168,169]. However, it has not been clarified whether the changes have clinical relevance. Exercise affects renal excretion, for instance, by a shift to a higher urinary $\mathrm{pH}$. As mentioned before, this leads to neutralization of weakly basic drugs, limiting their excretion, while acidic drugs are ionized and are thus, more easily excreted [170]. Biliary excretion also changes with exercise. Bile acid flow and excretion is increased and intestinal reabsorption decreased, leading to higher excretion rates of cholesterol, for example [171].

\subsection{Clinical Studies on Exercise and Drug Effects}

Several clinical studies have been performed to investigate the effects of physical activity on drugs. Many of these studies focused on cardiovascular drugs, such as beta-blocking 
agents like atenolol or propranolol, the calcium channel blocker verapamil or digoxin. The results are relatively heterogeneous showing increased, decreased or unchanged drug plasma levels after exercise which might be due to the fact that study conditions differed drastically among each other. Healthy volunteers as well as patients on drug therapy were investigated and the modes of exercise comprised treadmill walking, cycling, stair climbing etc. over differing periods of time, with different intensity and various numbers of repetitions. Interestingly, in most cases, only pharmacokinetic parameters, such as plasma concentration or urinary excretion were determined, while clinical parameters such as blood pressure, in the case of beta-blockers, were not analyzed. Control groups were often not used for comparison and many of the studies included only low numbers of participants (reviewed in [6]). Further studies assessed the influence of exercise on the efficacy of warfarin. Similar to vitamin K rich food, the level of physical activity has an impact on warfarin effects in anticoagulation therapy. Highly active patients required higher doses of warfarin but showed a $38 \%$ lower risk of major hemorrhage. The mechanisms leading to these effects have not yet been clarified [172,173]. As mentioned previously, exercise also shows a strong effect on insulin-regulated blood glucose levels. Injection of insulin into different sites of the body was associated with an increase in insulin absorption, hyperinsulinemia and hypoglycemia in combination with physical activity [174-176]. Theophylline, which is used for the treatment of asthma patients, is also affected by exercise performance with increases in half-life and decreases in clearance, which might lead to toxic effects [177].

In spite of all the studies mentioned above, it is difficult to create a general model for exercise-drug interactions due to the fact that drugs as well as exercising individuals show heterogeneous properties with regard to their biochemical characteristics, for example, or the exercise type which is performed and the training status. This is even more complicated considering the administration routes of the drugs. Nevertheless, these studies at least indicate that exercise can affect the pharmacokinetics of drugs (e.g., some beta-blockers) with a narrow therapeutic index (ratio between beneficial and toxic doses), which is an important consideration when treating exercising patients with these drugs. In addition, diabetic patients on insulin need to be treated with caution and should be advised to monitor their blood glucose frequently during exercise.

In summary, it is well established that exercise can influence the pharmacokinetics of drugs [178], but the potential impact on therapeutic responses is still less clear. Currently, standardized clinical studies on these therapeutic changes are largely lacking, although an understanding of these drug-exercise interactions is extremely important, especially for patients with existing conditions on drug therapy with frequently prescribed or narrow therapeutic range drugs. Furthermore, such insight could support the efficacy and also the safety of newly developed drugs. The problem with exercise, as with diet, is its high heterogeneity with regard to the level of exhaustion, and whether aerobic or anaerobic exercise, endurance or strength training is exerted. Furthermore, it is not known which and how many molecular responses are induced by exercise and which are regulated by other biological conditions, such as age, gender, genetic precondition and nutrition, thus making a distinction of sport effects on drug efficacy even more complicated. Nonetheless, the pharmacokinetic parameters of most medications are typically assessed under resting and non-stressful conditions, and consequently the potential for drug-exercise interactions may have been underreported. Clinical studies integrating physical activity are mostly performed in young healthy volunteers who exert single bouts of a specific type of exercise to achieve some standardization of the studies. However, these study conditions do not mirror a realistic clinical situation and therefore, the clinical significance is often questionable. It would be extremely important to also perform these studies in patients with different diseases and on different drug therapies, but under standardized conditions for the exercise program. Furthermore, studies on different types of long-term continuous exercise are needed, since first hints indicate that the duration of exercise may make a large difference $[166,179]$. 
Standardization of exercise conditions in clinical studies might be facilitated by clearly defined study protocols and population subsets. Furthermore, a combination of studies performed at different research institutions would clearly advance our knowledge on exercise effects. Then it might also be possible to adjust therapies individually for different patient populations by distinguishing between physically active and inactive individuals, for instance, and integrating their fitness level as well as the intensity and type of exercise.

\section{Concluding Remarks}

Exercise and dietary changes are often recommended as basic or concomitant therapeutic measures in several diseases. Their beneficial properties are undoubted but their potential effects on drug efficacy are often not respected, although they may have an impact on the therapeutic outcome in individual patients. Several scientific approaches have tried to clarify pharmacodynamic and pharmacokinetic changes induced by exercise and dietary interventions, but there are still many open questions left. A big problem in this context is the high variability of lifestyle-induced effects. It is obvious that exercise and diet are parameters which are highly variable and depend on a large number of different prerequisites. Interactions between food, exercise and drugs are almost limitless and depend on type of food/exercise, strength, route of administration of the drug, the drug chemical properties, genetic predisposition or microbiome of patients, to give some examples. Exercise- or diet-induced physiological changes can be short- or long-term and might affect the food-drug or exercise-drug interactions, probably to some degree through alterations in the gut microbiome which has rarely been investigated so far. A further point is that effects differ largely from drug to drug and effects of single drugs or drug classes do not necessarily reflect effects on other drugs. Since it might not be possible to comprehensively clarify all diet-drug, exercise-drug interactions, the occurrence of pharmacological plasticity might be overcome by applying several different alternative measures, such as increasing the specificity of newly developed drugs for patient sub-populations. A further possible solution to optimize the therapy under lifestyle changes would be a multifactorial approach using sequential therapeutic approaches with different drug types to determine which treatment provides the optimal therapeutic outcome [1]. In any case, it must be taken into account that drug dosage may need to be adjusted after or during lifestyle changes, as different types of pharmacological plasticity lead to changes in drug efficacy and toxicity. This is particularly important for drugs with a narrow therapeutic window. Patients taking such drugs should be informed and carefully monitored. On the other hand, it should also be kept in mind that, in some cases, lifestyle-induced effects on drug responses may be statistically significant but have limited clinical relevance.

In conclusion, data summarized in this review indicate that lifestyle changes in diet or physical activity induce a wide spectrum of pharmacological plasticity which might interfere with the efficacy and toxicity of several drugs. These potential interactions should be considered by physicians and patients as well as during the development of novel therapeutic drugs.

Author Contributions: Conceptualization, M.J.P.; Writing—original draft, E.N.; Writing—review and editing, E.N. and M.J.P. All authors have read and agreed to the published version of the manuscript.

Funding: This research received no external funding.

Institutional Review Board Statement: Not applicable.

Informed Consent Statement: Not applicable.

Data Availability Statement: PubMed Database, Citation lists of initially read publications.

Conflicts of Interest: The authors declare no conflict of interest. 


$\begin{array}{ll}\text { Abbreviations } \\ \text { ADME } & \text { Adsorption, Distribution, Metabolism, Elimination } \\ \text { Cyp } & \text { Cytochrome } \\ \text { FDA } & \text { Food and Drug administration } \\ \text { FFA } & \text { Free fatty acid } \\ \text { GI } & \text { Gastrointestinal } \\ \text { GPCR } & \text { G-Protein coupled receptor } \\ \text { PD } & \text { Pharmacodynamics } \\ \text { PK } & \text { Pharmacokinetics } \\ \text { Pgp } & \text { P-glycoprotein } \\ \text { PUFA } & \text { Polyunsaturated fatty acids }\end{array}$

\section{References}

1. Parnham, M.J.; Geisslinger, G. Pharmacological plasticity-How do you hit a moving target? Pharmacol. Res. Perspect. 2019, 7, e00532. [CrossRef]

2. Hauser, A.S.; Chavali, S.; Masuho, I.; Jahn, L.J.; Martemyanov, K.A.; Gloriam, D.E.; Babu, M.M. Pharmacogenomics of GPCR Drug Targets. Cell 2018, 172, 41-54.e19. [CrossRef] [PubMed]

3. Holohan, C.; Van Schaeybroeck, S.; Longley, D.B.; Johnston, P.G. Cancer drug resistance: An evolving paradigm. Nat. Rev. Cancer 2013, 13, 714-726. [CrossRef]

4. Cohen, J.L. Pharmacokinetic changes in aging. Am. J. Med. 1986, 80, 31-38. [CrossRef]

5. Walter-Sack, I.; Klotz, U. Influence of diet and nutritional status on drug metabolism. Clin. Pharmacokinet. 1996, 31, 47-64. [CrossRef]

6. Lenz, T.L.; Lenz, N.J.; Faulkner, M.A. Potential interactions between exercise and drug therapy. Sports Med. 2004, 34, 293-306. [CrossRef] [PubMed]

7. Zarezadeh, M.; Saedisomeolia, A.; Shekarabi, M.; Khorshidi, M.; Emami, M.R.; Muller, D.J. The effect of obesity, macronutrients, fasting and nutritional status on drug-metabolizing cytochrome P450s: A systematic review of current evidence on human studies. Eur. J. Nutr. 2020. [CrossRef] [PubMed]

8. Wilson, D.E.; Van Vlack, T.; Schievink, B.P.; Doak, E.B.; Shane, J.S.; Dean, E. Lifestyle factors in hypertension drug research: Systematic analysis of articles in a leading cochrane report. Int. J. Hypertens. 2014, 2014, 835716. [CrossRef]

9. Miller, L.G. Cigarettes and drug therapy: Pharmacokinetic and pharmacodynamic considerations. Clin. Pharmacol. 1990, 9, 125-135.

10. Mattson, M.P. Energy intake and exercise as determinants of brain health and vulnerability to injury and disease. Cell Metab. 2012, 16, 706-722. [CrossRef] [PubMed]

11. Walsh, N.P.; Gleeson, M.; Shephard, R.J.; Gleeson, M.; Woods, J.A.; Bishop, N.C.; Fleshner, M.; Green, C.; Pedersen, B.K.; Hoffman-Goetz, L.; et al. Position statement. Part one: Immune function and exercise. Exerc. Immunol. Rev. 2011, 17, 6-63.

12. Cheymol, G. Clinical pharmacokinetics of drugs in obesity. An update. Clin. Pharmacokinet. 1993, 25, 103-114. [CrossRef] [PubMed]

13. McLaughlin, M.; Jacobs, I. Exercise Is Medicine, But Does It Interfere With Medicine? Exerc. Sport Sci. Rev. 2017, 45, 127-135. [CrossRef] [PubMed]

14. Zanger, U.M.; Schwab, M. Cytochrome P450 enzymes in drug metabolism: Regulation of gene expression, enzyme activities, and impact of genetic variation. Pharmacol. Ther. 2013, 138, 103-141. [CrossRef] [PubMed]

15. Li, A.P.; Kaminski, D.L.; Rasmussen, A. Substrates of human hepatic cytochrome P450 3A4. Toxicology 1995, 104, 1-8. [CrossRef]

16. Wilkinson, G.R. Drug metabolism and variability among patients in drug response. N. Engl. J. Med. 2005, 352, 2211-2221. [CrossRef] [PubMed]

17. Knibbe, C.A.; Brill, M.J.; van Rongen, A.; Diepstraten, J.; van der Graaf, P.H.; Danhof, M. Drug disposition in obesity: Toward evidence-based dosing. Annu. Rev. Pharmacol. Toxicol. 2015, 55, 149-167. [CrossRef]

18. Hanley, M.J.; Abernethy, D.R.; Greenblatt, D.J. Effect of obesity on the pharmacokinetics of drugs in humans. Clin. Pharmacokinet. 2010, 49, 71-87. [CrossRef] [PubMed]

19. Trobec, K.; Kerec Kos, M.; von Haehling, S.; Springer, J.; Anker, S.D.; Lainscak, M. Pharmacokinetics of drugs in cachectic patients: A systematic review. PLoS ONE 2013, 8, e79603. [CrossRef] [PubMed]

20. O'Shea, J.P.; Holm, R.; O'Driscoll, C.M.; Griffin, B.T. Food for thought: Formulating away the food effect-A PEARRL review. J. Pharm. Pharmacol. 2019, 71, 510-535. [CrossRef] [PubMed]

21. Schmidt, L.E.; Dalhoff, K. Food-drug interactions. Drugs 2002, 62, 1481-1502. [CrossRef]

22. Liedholm, H.; Wahlin-Boll, E.; Melander, A. Mechanisms and variations in the food effect on propranolol bioavailability. Eur. J. Clin. Pharmacol. 1990, 38, 469-475. [CrossRef]

23. Augustijns, P.; Wuyts, B.; Hens, B.; Annaert, P.; Butler, J.; Brouwers, J. A review of drug solubility in human intestinal fluids: Implications for the prediction of oral absorption. Eur. J. Pharmaceut. Sci. 2014, 57, 322-332. [CrossRef]

24. Benet, L.Z.; Cummins, C.L.; Wu, C.Y. Unmasking the dynamic interplay between efflux transporters and metabolic enzymes. Int. J. Pharm. 2004, 277, 3-9. [CrossRef] 
25. Tamai, I. Oral drug delivery utilizing intestinal OATP transporters. Adv. Drug Deliv. Rev. 2012, 64, 508-514. [CrossRef] [PubMed]

26. Cheymol, G. Effects of obesity on pharmacokinetics implications for drug therapy. Clin. Pharmacokinet. 2000, 39, 215-231. [CrossRef] [PubMed]

27. Martin, J.H.; Saleem, M.; Looke, D. Therapeutic drug monitoring to adjust dosing in morbid obesity-A new use for an old methodology. Br. J. Clin. Pharmacol. 2012, 73, 685-690. [CrossRef]

28. Gagnon-Auger, M.; du Souich, P.; Baillargeon, J.P.; Martin, E.; Brassard, P.; Menard, J.; Ardilouze, J.L. Dose-dependent delay of the hypoglycemic effect of short-acting insulin analogs in obese subjects with type 2 diabetes: A pharmacokinetic and pharmacodynamic study. Diabetes Care 2010, 33, 2502-2507. [CrossRef]

29. Chan, C.C.; Ng, E.H.; Chan, M.M.; Tang, O.S.; Lau, E.Y.; Yeung, W.S.; Ho, P.C. Bioavailability of hCG after intramuscular or subcutaneous injection in obese and non-obese women. Hum. Reprod. 2003, 18, 2294-2297. [CrossRef]

30. Brill, M.J.; Diepstraten, J.; van Rongen, A.; van Kralingen, S.; van den Anker, J.N.; Knibbe, C.A. Impact of obesity on drug metabolism and elimination in adults and children. Clin. Pharmacokinet. 2012, 51, 277-304. [CrossRef]

31. Kotlyar, M.; Carson, S.W. Effects of obesity on the cytochrome P450 enzyme system. Int. J. Clin. Pharmacol. Ther. 1999, 37, 8-19. [PubMed]

32. Sandvik, P.; Lydersen, S.; Hegstad, S.; Spigset, O. Association between low body weight and cytochrome P-450 enzyme activity in patients with anorexia nervosa. Pharmacol. Res. Perspect. 2020, 8, e00615. [CrossRef]

33. Hole, K.; Heiberg, P.L.; Gjestad, C.; Mehus, L.L.; Ro, O.; Molden, E. Elevated 4beta-hydroxycholesterol/cholesterol ratio in anorexia nervosa patients. Pharmacol. Res. Perspect. 2018, 6, e00430. [CrossRef]

34. Maric-Bilkan, C. Obesity and diabetic kidney disease. Med. Clin. N. Am. 2013, 97, 59-74. [CrossRef] [PubMed]

35. Anderson, K.E.; Kappas, A. Dietary regulation of cytochrome P450. Annu. Rev. Nutr. 1991, 11, 141-167. [CrossRef] [PubMed]

36. Singh, B.N. Effects of food on clinical pharmacokinetics. Clin. Pharmacokinet. 1999, 37, 213-255. [CrossRef]

37. Welling, P.G. Effects of food on drug absorption. Pharmacol. Ther. 1989, 43, 425-441. [CrossRef]

38. Stacher, G.; Granser, G.V.; Bergmann, H.; Kugi, A.; Stacher-Janotta, G.; Hobart, J. Slow gastric emptying induced by high fat content of meal accelerated by cisapride administered rectally. Dig. Dis. Sci. 1991, 36, 1259-1265. [CrossRef]

39. Zimmermann, T.; Yeates, R.A.; Laufen, H.; Pfaff, G.; Wildfeuer, A. Influence of concomitant food intake on the oral absorption of two triazole antifungal agents, itraconazole and fluconazole. Eur. J. Clin. Pharmacol. 1994, 46, 147-150. [CrossRef]

40. Melander, A.; Stenberg, P.; Liedholm, H.; Schersten, B.; Wahlin-Boll, E. Food-induced reduction in bioavailability of atenolol. Eur. J. Clin. Pharmacol. 1979, 16, 327-330. [CrossRef]

41. Deng, J.; Zhu, X.; Chen, Z.; Fan, C.H.; Kwan, H.S.; Wong, C.H.; Shek, K.Y.; Zuo, Z.; Lam, T.N. A Review of Food-Drug Interactions on Oral Drug Absorption. Drugs 2017, 77, 1833-1855. [CrossRef] [PubMed]

42. Tan, K.K.; Trull, A.K.; Uttridge, J.A.; Metcalfe, S.; Heyes, C.S.; Facey, S.; Evans, D.B. Effect of dietary fat on the pharmacokinetics and pharmacodynamics of cyclosporine in kidney transplant recipients. Clin. Pharmacol. Ther. 1995, 57, 425-433. [CrossRef]

43. Achterbergh, R.; Lammers, L.A.; van Nierop, S.; Klumpen, H.J.; Soeters, M.R.; Mathot, R.A.; Romijn, J.A. A short-term high fat diet increases exposure to midazolam and omeprazole in healthy subjects. Expert Opin. Drug Metab. Toxicol. 2016, 12, 715-720. [CrossRef] [PubMed]

44. Spector, A.A.; Kim, H.Y. Cytochrome P450 epoxygenase pathway of polyunsaturated fatty acid metabolism. Biochim. Biophys. Acta 2015, 1851, 356-365. [CrossRef] [PubMed]

45. Fetterman, J.W., Jr.; Zdanowicz, M.M. Therapeutic potential of n-3 polyunsaturated fatty acids in disease. Am. J. Health Syst. Pharm. 2009, 66, 1169-1179. [CrossRef] [PubMed]

46. Stubbs, C.D.; Smith, A.D. The modification of mammalian membrane polyunsaturated fatty acid composition in relation to membrane fluidity and function. Biochim. Biophys. Acta 1984, 779, 89-137. [CrossRef]

47. Oseid, D.E.; Song, L.; Lear, S.; Robinson, A.S. Nuclear translocation of the unliganded glucocorticoid receptor is influenced by membrane fluidity, but not A2AR agonism. Steroids 2020, 160, 108641. [CrossRef]

48. Guixa-Gonzalez, R.; Javanainen, M.; Gomez-Soler, M.; Cordobilla, B.; Domingo, J.C.; Sanz, F.; Pastor, M.; Ciruela, F.; MartinezSeara, H.; Selent, J. Membrane omega-3 fatty acids modulate the oligomerisation kinetics of adenosine A2A and dopamine D2 receptors. Sci. Rep. 2016, 6, 19839. [CrossRef]

49. Bousquet, M.; Saint-Pierre, M.; Julien, C.; Salem, N., Jr.; Cicchetti, F.; Calon, F. Beneficial effects of dietary omega-3 polyunsaturated fatty acid on toxin-induced neuronal degeneration in an animal model of Parkinson's disease. FASEB J. 2008, 22, 1213-1225. [CrossRef]

50. Pardini, R.S. Nutritional intervention with omega-3 fatty acids enhances tumor response to anti-neoplastic agents. Chem. Biol. Interact. 2006, 162, 89-105. [CrossRef]

51. Robertson, D.R.; Higginson, I.; Macklin, B.S.; Renwick, A.G.; Waller, D.G.; George, C.F. The influence of protein containing meals on the pharmacokinetics of levodopa in healthy volunteers. Br. J. Clin. Pharmacol. 1991, 31, 413-417. [CrossRef] [PubMed]

52. Fagan, T.C.; Walle, T.; Oexmann, M.J.; Walle, U.K.; Bai, S.A.; Gaffney, T.E. Increased clearance of propranolol and theophylline by high-protein compared with high-carbohydrate diet. Clin. Pharmacol. Ther. 1987, 41, 402-406. [CrossRef]

53. Anderson, K.E.; McCleery, R.B.; Vesell, E.S.; Vickers, F.F.; Kappas, A. Diet and cimetidine induce comparable changes in theophylline metabolism in normal subjects. Hepatology 1991, 13, 941-946. [CrossRef]

54. Feldman, C.H.; Hutchinson, V.E.; Sher, T.H.; Feldman, B.R.; Davis, W.J. Interaction between nutrition and theophylline metabolism in children. Ther. Drug Monit. 1982, 4, 69-76. [CrossRef] [PubMed] 
55. Thompson, P.J.; Skypala, I.; Dawson, S.; McAllister, W.A.; Turner Warwick, M. The effect of diet upon serum concentrations of theophylline. Br. J. Clin. Pharmacol. 1983, 16, 267-270. [CrossRef]

56. Bekersky, I.; Dressler, D.; Mekki, Q.A. Effect of low- and high-fat meals on tacrolimus absorption following $5 \mathrm{mg}$ single oral doses to healthy human subjects. J. Clin. Pharmacol. 2001, 41, 176-182. [CrossRef] [PubMed]

57. Balabaud, C.; Vinon, G.; Paccalin, J. Influence of dietary protein and carbohydrate on phenytoin metabolism in man. Br. J. Clin. Pharmacol. 1979, 8, 369-371. [CrossRef] [PubMed]

58. Lammers, L.A.; Achterbergh, R.; van Schaik, R.H.N.; Romijn, J.A.; Mathot, R.A.A. Effect of Short-Term Fasting on Systemic Cytochrome P450-Mediated Drug Metabolism in Healthy Subjects: A Randomized, Controlled, Crossover Study Using a Cocktail Approach. Clin. Pharmacokinet. 2017, 56, 1231-1244. [CrossRef] [PubMed]

59. Reidenberg, M.M.; Vesell, E.S. Unaltered metabolism of antipyrine and tolbutamide in fasting man. Clin. Pharmacol. Ther. 1975, 17, 650-656. [CrossRef]

60. Lammers, L.A.; Achterbergh, R.; Romijn, J.A.; Mathot, R.A.A. Nutritional Status Differentially Alters Cytochrome P450 3A4 (CYP3A4) and Uridine 5'-Diphospho-Glucuronosyltransferase (UGT) Mediated Drug Metabolism: Effect of Short-Term Fasting and High Fat Diet on Midazolam Metabolism. Eur. J. Drug Metab. Pharmacokinet. 2018, 43, 751-767. [CrossRef]

61. Opara, E.C.; Rockway, S.W. Antioxidants and micronutrients. Dis. Mon. 2006, 52, 151-163. [CrossRef] [PubMed]

62. DellaPenna, D. Nutritional genomics: Manipulating plant micronutrients to improve human health. Science 1999, 285, 375-379. [CrossRef]

63. Boullata, J.I.; Hudson, L.M. Drug-nutrient interactions: A broad view with implications for practice. J. Acad. Nutr. Diet. 2012, 112, 506-517. [CrossRef]

64. Gibaldi, M.; Grundhofer, B.; Levy, G. Effect of antacids on pH of urine. Clin. Pharmacol. Ther. 1974, 16, 520-525. [CrossRef]

65. Neuvonen, P.J.; Kivisto, K.T. Enhancement of drug absorption by antacids. An unrecognised drug interaction. Clin. Pharmacokinet. 1994, 27, 120-128. [CrossRef] [PubMed]

66. D'Arcy, P.F.; McElnay, J.C. Drug-antacid interactions: Assessment of clinical importance. Drug Intell. Clin. Pharm. 1987, 21, 607-617. [CrossRef]

67. Abushouk, A.I.; Reggi, R.; Yarla, N.S.; Palmery, M.; Peluso, I. Association of antioxidant nutraceuticals and acetaminophen (paracetamol): Friend or foe? J. Food Drug Anal. 2018, 26, S78-S87.

68. Gougis, P.; Hilmi, M.; Geraud, A.; Mir, O.; Funck-Brentano, C. Potential Cytochrome P450-mediated pharmacokinetic interactions between herbs, food, and dietary supplements and cancer treatments. Crit. Rev. Oncol. Hematol. 2021, 10, 42. [CrossRef]

69. Hano, C.; Tungmunnithum, D. Plant Polyphenols, More than Just Simple Natural Antioxidants: Oxidative Stress, Aging and Age-Related Diseases. Medicines (Basel) 2020, 7, 26. [CrossRef]

70. Williamson, G.; Sheedy, K. Effects of Polyphenols on Insulin Resistance. Nutrients 2020, 12, 3135. [CrossRef]

71. Peluso, I.; Palmery, M.; Serafini, M. Association of flavonoid-rich foods and statins in the management of hypercholesterolemia: A dangerous or helpful combination? Curr. Drug Metab. 2015, 16, 833-846. [CrossRef]

72. Bailey, D.G.; Malcolm, J.; Arnold, O.; Spence, J.D. Grapefruit juice-drug interactions. Br. J. Clin. Pharmacol. 1998, 46, 101-110. [CrossRef]

73. Dresser, G.K.; Bailey, D.G.; Leake, B.F.; Schwarz, U.I.; Dawson, P.A.; Freeman, D.J;; Kim, R.B. Fruit juices inhibit organic anion transporting polypeptide-mediated drug uptake to decrease the oral availability of fexofenadine. Clin. Pharmacol. Ther. 2002, 71, 11-20. [CrossRef] [PubMed]

74. Liu, X. Transporter-Mediated Drug-Drug Interactions and Their Significance. Adv. Exp. Med. Biol. 2019, 1141, 241-291. [CrossRef] [PubMed]

75. Bailey, D.G.; Dresser, G.; Arnold, J.M. Grapefruit-medication interactions: Forbidden fruit or avoidable consequences? CMAJ 2013, 185, 309-316. [CrossRef] [PubMed]

76. Seden, K.; Dickinson, L.; Khoo, S.; Back, D. Grapefruit-drug interactions. Drugs 2010, 70, 2373-2407. [CrossRef]

77. Lilja, J.J.; Backman, J.T.; Laitila, J.; Luurila, H.; Neuvonen, P.J. Itraconazole increases but grapefruit juice greatly decreases plasma concentrations of celiprolol. Clin. Pharmacol. Ther. 2003, 73, 192-198. [CrossRef]

78. Petric, Z.; Zuntar, I.; Putnik, P.; Bursac Kovacevic, D. Food-Drug Interactions with Fruit Juices. Foods 2020, 10, 33. [CrossRef] [PubMed]

79. Chen, M.; Zhou, S.Y.; Fabriaga, E.; Zhang, P.H.; Zhou, Q. Food-drug interactions precipitated by fruit juices other than grapefruit juice: An update review. J. Food Drug Anal. 2018, 26, S61-S71. [CrossRef]

80. Abernethy, D.R. Grapefruits and drugs: When is statistically significant clinically significant? J. Clin. Investig. 1997, 99, 2297-2298. [CrossRef] [PubMed]

81. Ronis, M.J. Effects of soy containing diet and isoflavones on cytochrome P450 enzyme expression and activity. Drug Metab. Rev. 2016, 48, 331-341. [CrossRef]

82. Chen, Y.; Xiao, C.Q.; He, Y.J.; Chen, B.L.; Wang, G.; Zhou, G.; Zhang, W.; Tan, Z.R.; Cao, S.; Wang, L.P.; et al. Genistein alters caffeine exposure in healthy female volunteers. Eur. J. Clin. Pharmacol. 2011, 67, 347-353. [CrossRef]

83. Nakajima, M.; Itoh, M.; Yamanaka, H.; Fukami, T.; Tokudome, S.; Yamamoto, Y.; Yamamoto, H.; Yokoi, T. Isoflavones inhibit nicotine C-oxidation catalyzed by human CYP2A6. J. Clin. Pharmacol. 2006, 46, 337-344. [CrossRef]

84. Xiao, C.Q.; Chen, R.; Lin, J.; Wang, G.; Chen, Y.; Tan, Z.R.; Zhou, H.H. Effect of genistein on the activities of cytochrome P450 3A and P-glycoprotein in Chinese healthy participants. Xenobiotica 2012, 42, 173-178. [CrossRef] 
85. Cao, L.; Kwara, A.; Greenblatt, D.J. Metabolic interactions between acetaminophen (paracetamol) and two flavonoids, luteolin and quercetin, through in-vitro inhibition studies. J. Pharm. Pharmacol. 2017, 69, 1762-1772. [CrossRef] [PubMed]

86. Hilliard, A.; Mendonca, P.; Russell, T.D.; Soliman, K.F.A. The Protective Effects of Flavonoids in Cataract Formation through the Activation of Nrf2 and the Inhibition of MMP-9. Nutrients 2020, 12, 3651. [CrossRef] [PubMed]

87. Gunne, S.; Heinicke, U.; Parnham, M.J.; Laux, V.; Zacharowski, K.; von Knethen, A. Nrf2-A Molecular Target for Sepsis Patients in Critical Care. Biomolecules 2020, 10, 1688. [CrossRef] [PubMed]

88. Gupta, N.; Verma, K.; Nalla, S.; Kulshreshtha, A.; Lall, R.; Prasad, S. Free Radicals as a Double-Edged Sword: The Cancer Preventive and Therapeutic Roles of Curcumin. Molecules 2020, 25, 5390. [CrossRef]

89. Habtemariam, S. Antioxidant and Anti-inflammatory Mechanisms of Neuroprotection by Ursolic Acid: Addressing Brain Injury, Cerebral Ischemia, Cognition Deficit, Anxiety, and Depression. Oxid. Med. Cell. Longev. 2019, 2019, 8512048. [CrossRef]

90. Maucher, I.V.; Ruhl, M.; Kretschmer, S.B.; Hofmann, B.; Kuhn, B.; Fettel, J.; Vogel, A.; Flugel, K.T.; Manolikakes, G.; Hellmuth, N.; et al. Michael acceptor containing drugs are a novel class of 5-lipoxygenase inhibitor targeting the surface cysteines C416 and C418. Biochem. Pharmacol. 2017, 125, 55-74. [CrossRef] [PubMed]

91. Taguchi, K.; Kensler, T.W. Nrf2 in liver toxicology. Arch. Pharm. Res. 2020, 43, 337-349. [CrossRef]

92. Suraweera, T.L.; Rupasinghe, H.P.V.; Dellaire, G.; Xu, Z. Regulation of Nrf2/ARE Pathway by Dietary Flavonoids: A Friend or Foe for Cancer Management? Antioxidants (Basel) 2020, 9, 973. [CrossRef]

93. Pantuck, E.J.; Pantuck, C.B.; Anderson, K.E.; Wattenberg, L.W.; Conney, A.H.; Kappas, A. Effect of brussels sprouts and cabbage on drug conjugation. Clin. Pharmacol. Ther. 1984, 35, 161-169. [CrossRef]

94. Pantuck, E.J.; Pantuck, C.B.; Garland, W.A.; Min, B.H.; Wattenberg, L.W.; Anderson, K.E.; Kappas, A.; Conney, A.H. Stimulatory effect of brussels sprouts and cabbage on human drug metabolism. Clin. Pharmacol. Ther. 1979, 25, 88-95. [CrossRef] [PubMed]

95. Kall, M.A.; Vang, O.; Clausen, J. Effects of dietary broccoli on human in vivo drug metabolizing enzymes: Evaluation of caffeine, oestrone and chlorzoxazone metabolism. Carcinogenesis 1996, 17, 793-799. [CrossRef]

96. Kim, R.B.; O'Shea, D. Interindividual variability of chlorzoxazone 6-hydroxylation in men and women and its relationship to CYP2E1 genetic polymorphisms. Clin. Pharmacol. Ther. 1995, 57, 645-655. [CrossRef]

97. Chen, L.; Mohr, S.N.; Yang, C.S. Decrease of plasma and urinary oxidative metabolites of acetaminophen after consumption of watercress by human volunteers. Clin. Pharmacol. Ther. 1996, 60, 651-660. [CrossRef]

98. Neuvonen, P.J. Interactions with the absorption of tetracyclines. Drugs 1976, 11, 45-54. [CrossRef] [PubMed]

99. Leyden, J.J. Absorption of minocycline hydrochloride and tetracycline hydrochloride. Effect of food, milk, and iron. J. Am. Acad. Dermatol. 1985, 12, 308-312. [CrossRef]

100. Karlson, B.; Leijd, B.; Hellstrom, K. On the influence of vitamin K-rich vegetables and wine on the effectiveness of warfarin treatment. Acta Med. Scand. 1986, 220, 347-350. [CrossRef] [PubMed]

101. Kempin, S.J. Warfarin resistance caused by broccoli. N. Engl. J. Med. 1983, 308, 1229-1230. [CrossRef]

102. Baylis, E.M.; Crowley, J.M.; Preece, J.M.; Sylvester, P.E.; Marks, V. Influence of folic acid on blood-phenytoin levels. Lancet 1971, 1, 62-64. [CrossRef]

103. Furlanut, M.; Benetello, P.; Avogaro, A.; Dainese, R. Effects of folic acid on phenytoin kinetics in healthy subjects. Clin. Pharmacol. Ther. 1978, 24, 294-297. [CrossRef] [PubMed]

104. Back, D.J.; Breckenridge, A.M.; MacIver, M.; Orme, M.L.; Purba, H.; Rowe, P.H. Interaction of ethinyloestradiol with ascorbic acid in man. Br. Med. J. (Clin. Res. Ed.) 1981, 282, 1516. [CrossRef] [PubMed]

105. Briggs, M.H. Megadose vitamin C and metabolic effects of the pill. Br. Med. J. (Clin. Res. Ed.) 1981, 283, 1547. [CrossRef] [PubMed]

106. Zelfand, E. Vitamin C, Pain and Opioid Use Disorder. Integr. Med. 2020, 19, 18-29.

107. Murray, M. Altered CYP expression and function in response to dietary factors: Potential roles in disease pathogenesis. Curr. Drug Metab. 2006, 7, 67-81. [CrossRef]

108. Wang, Z.; Schuetz, E.G.; Xu, Y.; Thummel, K.E. Interplay between vitamin D and the drug metabolizing enzyme CYP3A4. J. Steroid Biochem. Mol. Biol. 2013, 136, 54-58. [CrossRef]

109. Hegazy, A.M.; El-Sayed, E.M.; Ibrahim, K.S.; Abdel-Azeem, A.S. Dietary antioxidant for disease prevention corroborated by the Nrf2 pathway. J. Complement. Integr. Med. 2019, 16. [CrossRef]

110. Human Microbiome Project, C. Structure, function and diversity of the healthy human microbiome. Nature 2012, 486, 207-214. [CrossRef]

111. Singh, R.K.; Chang, H.W.; Yan, D.; Lee, K.M.; Ucmak, D.; Wong, K.; Abrouk, M.; Farahnik, B.; Nakamura, M.; Zhu, T.H.; et al. Influence of diet on the gut microbiome and implications for human health. J. Transl. Med. 2017, 15, 73. [CrossRef]

112. Selwyn, F.P.; Cheng, S.L.; Klaassen, C.D.; Cui, J.Y. Regulation of Hepatic Drug-Metabolizing Enzymes in Germ-Free Mice by Conventionalization and Probiotics. Drug Metab. Dispos. 2016, 44, 262-274. [CrossRef]

113. Selwyn, F.P.; Cheng, S.L.; Bammler, T.K.; Prasad, B.; Vrana, M.; Klaassen, C.; Cui, J.Y. Developmental Regulation of DrugProcessing Genes in Livers of Germ-Free Mice. Toxicol. Sci. 2015, 147, 84-103. [CrossRef]

114. Zimmermann, M.; Zimmermann-Kogadeeva, M.; Wegmann, R.; Goodman, A.L. Separating host and microbiome contributions to drug pharmacokinetics and toxicity. Science 2019, 363. [CrossRef] [PubMed]

115. Saad, R.; Rizkallah, M.R.; Aziz, R.K. Gut Pharmacomicrobiomics: The tip of an iceberg of complex interactions between drugs and gut-associated microbes. Gut Pathog. 2012, 4, 16. [CrossRef] 
116. Sharma, A.; Buschmann, M.M.; Gilbert, J.A. Pharmacomicrobiomics: The Holy Grail to Variability in Drug Response? Clin. Pharmacol. Ther. 2019, 106, 317-328. [CrossRef] [PubMed]

117. Zimmermann, M.; Zimmermann-Kogadeeva, M.; Wegmann, R.; Goodman, A.L. Mapping human microbiome drug metabolism by gut bacteria and their genes. Nature 2019, 570, 462-467. [CrossRef] [PubMed]

118. Koppel, N.; Maini Rekdal, V.; Balskus, E.P. Chemical transformation of xenobiotics by the human gut microbiota. Science 2017, 356. [CrossRef]

119. Routy, B.; Le Chatelier, E.; Derosa, L.; Duong, C.P.M.; Alou, M.T.; Daillere, R.; Fluckiger, A.; Messaoudene, M.; Rauber, C.; Roberti, M.P.; et al. Gut microbiome influences efficacy of PD-1-based immunotherapy against epithelial tumors. Science 2018, 359, 91-97. [CrossRef]

120. Gopalakrishnan, V.; Spencer, C.N.; Nezi, L.; Reuben, A.; Andrews, M.C.; Karpinets, T.V.; Prieto, P.A.; Vicente, D.; Hoffman, K.; Wei, S.C.; et al. Gut microbiome modulates response to anti-PD-1 immunotherapy in melanoma patients. Science 2018, 359, 97-103. [CrossRef] [PubMed]

121. Conlon, M.A.; Bird, A.R. The impact of diet and lifestyle on gut microbiota and human health. Nutrients 2014, 7, 17-44. [CrossRef]

122. Kolodziejczyk, A.A.; Zheng, D.; Elinav, E. Diet-microbiota interactions and personalized nutrition. Nat. Rev. Microbiol. 2019, 17, 742-753. [CrossRef]

123. Marchesi, J.R.; Adams, D.H.; Fava, F.; Hermes, G.D.; Hirschfield, G.M.; Hold, G.; Quraishi, M.N.; Kinross, J.; Smidt, H.; Tuohy, K.M.; et al. The gut microbiota and host health: A new clinical frontier. Gut 2016, 65, 330-339. [CrossRef] [PubMed]

124. Wu, G.D.; Chen, J.; Hoffmann, C.; Bittinger, K.; Chen, Y.Y.; Keilbaugh, S.A.; Bewtra, M.; Knights, D.; Walters, W.A.; Knight, R.; et al. Linking long-term dietary patterns with gut microbial enterotypes. Science 2011, 334, 105-108. [CrossRef] [PubMed]

125. David, L.A.; Maurice, C.F.; Carmody, R.N.; Gootenberg, D.B.; Button, J.E.; Wolfe, B.E.; Ling, A.V.; Devlin, A.S.; Varma, Y.; Fischbach, M.A.; et al. Diet rapidly and reproducibly alters the human gut microbiome. Nature 2014, 505, 559-563. [CrossRef] [PubMed]

126. Jantchou, P.; Morois, S.; Clavel-Chapelon, F.; Boutron-Ruault, M.C.; Carbonnel, F. Animal protein intake and risk of inflammatory bowel disease: The E3N prospective study. Am. J. Gastroenterol. 2010, 105, 2195-2201. [CrossRef] [PubMed]

127. Wolters, M.; Ahrens, J.; Romani-Perez, M.; Watkins, C.; Sanz, Y.; Benitez-Paez, A.; Stanton, C.; Gunther, K. Dietary fat, the gut microbiota, and metabolic health-A systematic review conducted within the MyNewGut project. Clin. Nutr. 2019, 38, 2504-2520. [CrossRef] [PubMed]

128. Watson, H.; Mitra, S.; Croden, F.C.; Taylor, M.; Wood, H.M.; Perry, S.L.; Spencer, J.A.; Quirke, P.; Toogood, G.J.; Lawton, C.L.; et al. A randomised trial of the effect of omega-3 polyunsaturated fatty acid supplements on the human intestinal microbiota. Gut 2018, 67, 1974-1983. [CrossRef] [PubMed]

129. Fava, F.; Gitau, R.; Griffin, B.A.; Gibson, G.R.; Tuohy, K.M.; Lovegrove, J.A. The type and quantity of dietary fat and carbohydrate alter faecal microbiome and short-chain fatty acid excretion in a metabolic syndrome 'at-risk' population. Int. J. Obes. (Lond.) 2013, 37, 216-223. [CrossRef]

130. Kaur, A.P.; Bhardwaj, S.; Dhanjal, D.S.; Nepovimova, E.; Cruz-Martins, N.; Kuca, K.; Chopra, C.; Singh, R.; Kumar, H.; Sen, F.; et al. Plant Prebiotics and Their Role in the Amelioration of Diseases. Biomolecules 2021, 11, 440. [CrossRef] [PubMed]

131. Anhe, F.F.; Pilon, G.; Roy, D.; Desjardins, Y.; Levy, E.; Marette, A. Triggering Akkermansia with dietary polyphenols: A new weapon to combat the metabolic syndrome? Gut Microbes 2016, 7, 146-153. [CrossRef] [PubMed]

132. Parnham, M.J.; Stepanić, V.; Tafferner, N.; Panek, M.; Verbanac, D. Mild Plant and Dietary Immunomodulators. In Nijkamp and Parnham's Principles of Immunopharmacology; Parnham, M.J., Nijkamp, F.P., Rossi, A.G., Eds.; Springer International Publishing: Cham, Switzerland, 2019; pp. 561-587.

133. Wu, D.; Lewis, E.D.; Pae, M.; Meydani, S.N. Nutritional Modulation of Immune Function: Analysis of Evidence, Mechanisms, and Clinical Relevance. Front. Immunol. 2018, 9, 3160. [CrossRef]

134. Avery, J.C.; Hoffmann, P.R. Selenium, Selenoproteins, and Immunity. Nutrients 2018, 10, 1203. [CrossRef] [PubMed]

135. Calder, P.C.; Grimble, R.F. Polyunsaturated fatty acids, inflammation and immunity. Eur. J. Clin. Nutr. 2002, 56 (Suppl. S3), S14-S19. [CrossRef] [PubMed]

136. Mendivil, C.O. Dietary Fish, Fish Nutrients, and Immune Function: A Review. Front. Nutr. 2020, 7, 617652. [CrossRef] [PubMed]

137. Radzikowska, U.; Rinaldi, A.O.; Celebi Sozener, Z.; Karaguzel, D.; Wojcik, M.; Cypryk, K.; Akdis, M.; Akdis, C.A.; Sokolowska, M. The Influence of Dietary Fatty Acids on Immune Responses. Nutrients 2019, 11, 990. [CrossRef]

138. Fournier, N.; Sayet, G.; Vedie, B.; Nowak, M.; Allaoui, F.; Solgadi, A.; Caudron, E.; Chaminade, P.; Benoist, J.F.; Paul, J.L. Eicosapentaenoic acid membrane incorporation impairs cholesterol efflux from cholesterol-loaded human macrophages by reducing the cholesteryl ester mobilization from lipid droplets. Biochim. Biophys. Acta Mol. Cell Biol. Lipids 2017, 1862, 1079-1091. [CrossRef] [PubMed]

139. Du, J.; Zhu, M.; Bao, H.; Li, B.; Dong, Y.; Xiao, C.; Zhang, G.Y.; Henter, I.; Rudorfer, M.; Vitiello, B. The Role of Nutrients in Protecting Mitochondrial Function and Neurotransmitter Signaling: Implications for the Treatment of Depression, PTSD, and Suicidal Behaviors. Crit. Rev. Food Sci. Nutr. 2016, 56, 2560-2578. [CrossRef] [PubMed]

140. Peet, M.; Stokes, C. Omega-3 fatty acids in the treatment of psychiatric disorders. Drugs 2005, 65, 1051-1059. [CrossRef] [PubMed]

141. Verma, S.P. HIV: A raft-targeting approach for prevention and therapy using plant-derived compounds (review). Curr. Drug Targets 2009, 10, 51-59. [CrossRef] [PubMed] 
142. Pepin, X.J.H.; Huckle, J.E.; Alluri, R.V.; Basu, S.; Dodd, S.; Parrott, N.; Emami Riedmaier, A. Understanding Mechanisms of Food Effect and Developing Reliable PBPK Models Using a Middle-out Approach. AAPS J. 2021, 23, 12. [CrossRef]

143. Tistaert, C.; Heimbach, T.; Xia, B.; Parrott, N.; Samant, T.S.; Kesisoglou, F. Food Effect Projections via Physiologically Based Pharmacokinetic Modeling: Predictive Case Studies. J. Pharm. Sci. 2019, 108, 592-602. [CrossRef] [PubMed]

144. Li, M.; Zhao, P.; Pan, Y.; Wagner, C. Predictive Performance of Physiologically Based Pharmacokinetic Models for the Effect of Food on Oral Drug Absorption: Current Status. CPT Pharmacomet. Syst. Pharmacol. 2018, 7, 82-89. [CrossRef] [PubMed]

145. Naci, H.; Ioannidis, J.P. Comparative effectiveness of exercise and drug interventions on mortality outcomes: Metaepidemiological study. BMJ 2013, 347, f5577. [CrossRef] [PubMed]

146. Vina, J.; Sanchis-Gomar, F.; Martinez-Bello, V.; Gomez-Cabrera, M.C. Exercise acts as a drug; the pharmacological benefits of exercise. Br. J. Pharmacol. 2012, 167, 1-12. [CrossRef] [PubMed]

147. Neufer, P.D.; Bamman, M.M.; Muoio, D.M.; Bouchard, C.; Cooper, D.M.; Goodpaster, B.H.; Booth, F.W.; Kohrt, W.M.; Gerszten, R.E.; Mattson, M.P.; et al. Understanding the Cellular and Molecular Mechanisms of Physical Activity-Induced Health Benefits. Cell Metab. 2015, 22, 4-11. [CrossRef]

148. Ter Steege, R.W.; Kolkman, J.J. Review article: The pathophysiology and management of gastrointestinal symptoms during physical exercise, and the role of splanchnic blood flow. Aliment. Pharmacol. Ther. 2012, 35, 516-528. [CrossRef]

149. Rowell, L.B. Human cardiovascular adjustments to exercise and thermal stress. Physiol. Rev. 1974, 54, 75-159. [CrossRef]

150. Brock-Utne, J.G.; Gaffin, S.L.; Wells, M.T.; Gathiram, P.; Sohar, E.; James, M.F.; Morrell, D.F.; Norman, R.J. Endotoxaemia in exhausted runners after a long-distance race. S. Afr. Med. J. 1988, 73, 533-536.

151. Jeukendrup, A.E.; Vet-Joop, K.; Sturk, A.; Stegen, J.H.; Senden, J.; Saris, W.H.; Wagenmakers, A.J. Relationship between gastrointestinal complaints and endotoxaemia, cytokine release and the acute-phase reaction during and after a long-distance triathlon in highly trained men. Clin. Sci. 2000, 98, 47-55. [CrossRef]

152. Koivisto, V.A.; Yki-Jarvinen, H.; DeFronzo, R.A. Physical training and insulin sensitivity. Diabetes Metab. Rev. 1986, 1, 445-481. [CrossRef]

153. Klemsdal, T.O.; Gjesdal, K.; Bredesen, J.E. Heating and cooling of the nitroglycerin patch application area modify the plasma level of nitroglycerin. Eur. J. Clin. Pharmacol. 1992, 43, 625-628. [CrossRef] [PubMed]

154. Gamble, J.A. Proceedings: Some factors influencing the absorption of diazepam. Proc. R. Soc. Med. 1975, 68, 772.

155. Schmidt, H.; Roholt, K. Penicillin serum concentrations in relation to exercise. Acta Pathol. Microbiol. Scand. 1966, 68, 396-400. [CrossRef] [PubMed]

156. Van Baak, M.A. Influence of exercise on the pharmacokinetics of drugs. Clin. Pharmacokinet. 1990, 19, 32-43. [CrossRef] [PubMed]

157. Novosadova, J. The changes in hematocrit, hemoglobin, plasma volume and proteins during and after different types of exercise. Eur. J. Appl. Physiol. Occup. Physiol. 1977, 36, 223-230. [CrossRef] [PubMed]

158. Van Baak, M.A.; Mooij, J.M.; Schiffers, P.M. Exercise and the pharmacokinetics of propranolol, verapamil and atenolol. Eur. J. Clin. Pharmacol. 1992, 43, 547-550. [CrossRef] [PubMed]

159. Hurwitz, G.A.; Webb, J.G.; Walle, T.; Bai, S.A.; Daniell, H.B.; Gourley, L.; Boyd Loadholt, C.; Gaffney, T.E. Exercise-induced increments in plasma levels of propranolol and noradrenaline. Br. J. Clin. Pharmacol. 1983, 16, 599-608. [CrossRef]

160. Tesseromatis, C.; Trichilis, A.; Tsivos, E.; Messari, J.; Triantaphyllidis, H.; Varonos, D.D. Does stress influence ampicillin concentration in serum and tissues? Eur. J. Drug Metab. Pharmacokinet. 2001, 26, 167-171. [CrossRef]

161. Saatmann, N.; Zaharia, O.P.; Loenneke, J.P.; Roden, M.; Pesta, D.H. Effects of Blood Flow Restriction Exercise and Possible Applications in Type 2 Diabetes. Trends Endocrinol. Metab. 2021, 32, 106-117. [CrossRef]

162. Nies, A.S.; Shand, D.G.; Wilkinson, G.R. Altered hepatic blood flow and drug disposition. Clin. Pharmacokinet. 1976, 1, 135-155. [CrossRef] [PubMed]

163. Shek, P.N.; Shephard, R.J. Physical exercise as a human model of limited inflammatory response. Can. J. Physiol. Pharmacol. 1998, 76, 589-597. [CrossRef] [PubMed]

164. Suzuki, K.; Totsuka, M.; Nakaji, S.; Yamada, M.; Kudoh, S.; Liu, Q.; Sugawara, K.; Yamaya, K.; Sato, K. Endurance exercise causes interaction among stress hormones, cytokines, neutrophil dynamics, and muscle damage. J. Appl. Physiol. 1999, 87, $1360-1367$. [CrossRef] [PubMed]

165. King-Himmelreich, T.S.; Schramm, S.; Wolters, M.C.; Schmetzer, J.; Moser, C.V.; Knothe, C.; Resch, E.; Peil, J.; Geisslinger, G.; Niederberger, E. The impact of endurance exercise on global and AMPK gene-specific DNA methylation. Biochem. Biophys. Res. Commun. 2016, 474, 284-290. [CrossRef] [PubMed]

166. Yiamouyiannis, C.A.; Sanders, R.A.; Watkins, J.B., 3rd; Martin, B.J. Chronic physical activity: Hepatic hypertrophy and increased total biotransformation enzyme activity. Biochem. Pharmacol. 1992, 44, 121-127. [CrossRef]

167. Hinderling, P.H.; Hartmann, D. The $\mathrm{pH}$ dependency of the binding of drugs to plasma proteins in man. Ther. Drug Monit. 2005, 27, 71-85. [CrossRef]

168. Stoschitzky, K.; Lindner, W.; Klein, W. Stereoselective release of (S)-atenolol from adrenergic nerve endings at exercise. Lancet 1992, 340, 696-697. [CrossRef]

169. Ylitalo, P.; Hinkka, H. Effect of exercise on plasma levels and urinary excretion of sulphadimidine and procainamide. Int. J. Clin. Pharmacol. Ther. Toxicol 1985, 23, 548-553. 
170. Moriguchi, T.; Shimomitsu, T.; Odagiri, Y.; Fukuda, J.; Hamano, K.; Kawai, T.; Tomoda, A. Marked increase in urinary bicarbonate and $\mathrm{pH}$ caused by heavy muscular exercise with dynamic knee extension. Tohoku J. Exp. Med. 2002, 198, 31-39. [CrossRef] [PubMed]

171. Meissner, M.; Lombardo, E.; Havinga, R.; Tietge, U.J.; Kuipers, F.; Groen, A.K. Voluntary wheel running increases bile acid as well as cholesterol excretion and decreases atherosclerosis in hypercholesterolemic mice. Atherosclerosis 2011, 218, 323-329. [CrossRef] [PubMed]

172. Shendre, A.; Beasley, T.M.; Brown, T.M.; Hill, C.E.; Arnett, D.K.; Limdi, N.A. Influence of regular physical activity on warfarin dose and risk of hemorrhagic complications. Pharmacotherapy 2014, 34, 545-554. [CrossRef] [PubMed]

173. Rouleau-Mailloux, E.; Shahabi, P.; Dumas, S.; Feroz Zada, Y.; Provost, S.; Hu, J.; Nguyen, J.; Bouchama, N.; Mongrain, I.; Talajic, M.; et al Impact of regular physical activity on weekly warfarin dose requirement. J. Thromb. Thrombolysis 2016, 41, 328-335. [CrossRef] [PubMed]

174. Susstrunk, H.; Morell, B.; Ziegler, W.H.; Froesch, E.R. Insulin absorption from the abdomen and the thigh in healthy subjects during rest and exercise: Blood glucose, plasma insulin, growth hormone, adrenaline and noradrenaline levels. Diabetologia 1982, 22, 171-174. [CrossRef] [PubMed]

175. Ferrannini, E.; Linde, B.; Faber, O. Effect of bicycle exercise on insulin absorption and subcutaneous blood flow in the normal subject. Clin. Physiol. 1982, 2, 59-70. [CrossRef]

176. McAuley, S.A.; Horsburgh, J.C.; Ward, G.M.; La Gerche, A.; Gooley, J.L.; Jenkins, A.J.; MacIsaac, R.J.; O’Neal, D.N. Insulin pump basal adjustment for exercise in type 1 diabetes: A randomised crossover study. Diabetologia 2016, 59, 1636-1644. [CrossRef]

177. Schlaeffer, F.; Engelberg, I.; Kaplanski, J.; Danon, A. Effect of exercise and environmental heat on theophylline kinetics. Respiration 1984, 45, 438-442. [CrossRef] [PubMed]

178. Lenz, T.L. The effects of high physical activity on pharmacokinetic drug interactions. Expert Opin. Drug Metab. Toxicol. 2011, 7, 257-266. [CrossRef]

179. Miyauchi, S.; Oshima, S.; Asaka, M.; Kawano, H.; Torii, S.; Higuchi, M. Organ size increases with weight gain in power-trained athletes. Int. J. Sport Nutr. Exerc. Metab. 2013, 23, 617-623. [CrossRef] 